\title{
Pit slopes in weathered and weak rocks
}

\author{
C.D. Martin University of Alberta, Canada \\ P.F. Stacey Stacey Mining Geotechnical Ltd., Canada
}

\begin{abstract}
The 'Guidelines for Open Pit Slope Design' developed as part of the Large Open Pit (LOP) project was published in 2009. The guidelines were focused on hard rocks in open pit mines so did not address design issues for pit slopes in materials generally classed as weak rocks. Research currently being undertaken by the LOP sponsors is directed at filling this gap.
\end{abstract}

Canvassing of the LOP sponsors and their affiliates resulted in identifying pit slope issues in five general categories of weak rocks:

1. Cemented transported sediments.

2. Saprolites (residual soils and weathered rocks).

3. Leached rocks/soft iron ores (leached, creating a rock with a high void ratio).

4. Mudrocks.

5. Hydrothermally altered rocks.

Establishing the strength of hard rocks is traditionally approached using rock mass classifications and the Hoek-Brown failure criterion. However, there is ample evidence that these approaches do not capture the strength characteristics and the failure processes evident in weak rocks. In this paper the authors describe some of the processes that should be considered when attempting to establish the strength and failure envelopes input into slope designs for open pits in weak rocks.

\section{$1 \quad$ Introduction}

'Guidelines for Open Pit Slope Design' was produced in 2009 (Read and Stacey, 2009). These guidelines were focused primarily on open pit slopes in hard rocks and did not address the challenges that are often associated with open pits in weak rocks. While open pits in weak rocks tend to be shallower than those in hard rocks, pit slopes several hundred metres deep have been developed in weak rock and hence failures can still be significant. Weak rocks typically require flatter slope angles than are used in hard rocks and these flatter slopes can also have significant economic impacts. It is therefore critical that the presence of weak rocks is recognised early in the design process, since they often cannot be mitigated in the same way as hard rocks. Because weak rocks were not addressed in the original guidelines, the LOP is in the process of compiling guidelines for open pit slope design in these weak rocks. The first step in this process was to canvass the mine operators to identify the material that they classed potentially as weak rock, and particularly the materials that presented operational challenges. All the results from that survey are summarised in Figure 1.

Each of the material types reported in Figure 1 has a unique geological origin and can behave in distinctly different ways in an excavated slope. While the initial survey results reported a broad range of rock types the focus for this study was restricted to weak rocks and hence the case histories for volcanic breccias, quartzites and kimberlites were excluded. The purpose of this paper is to provide an overview of the behaviour of slopes in weak rocks that has been observed in large open pits and provide a framework for characterising, analysing and designing in these materials. 


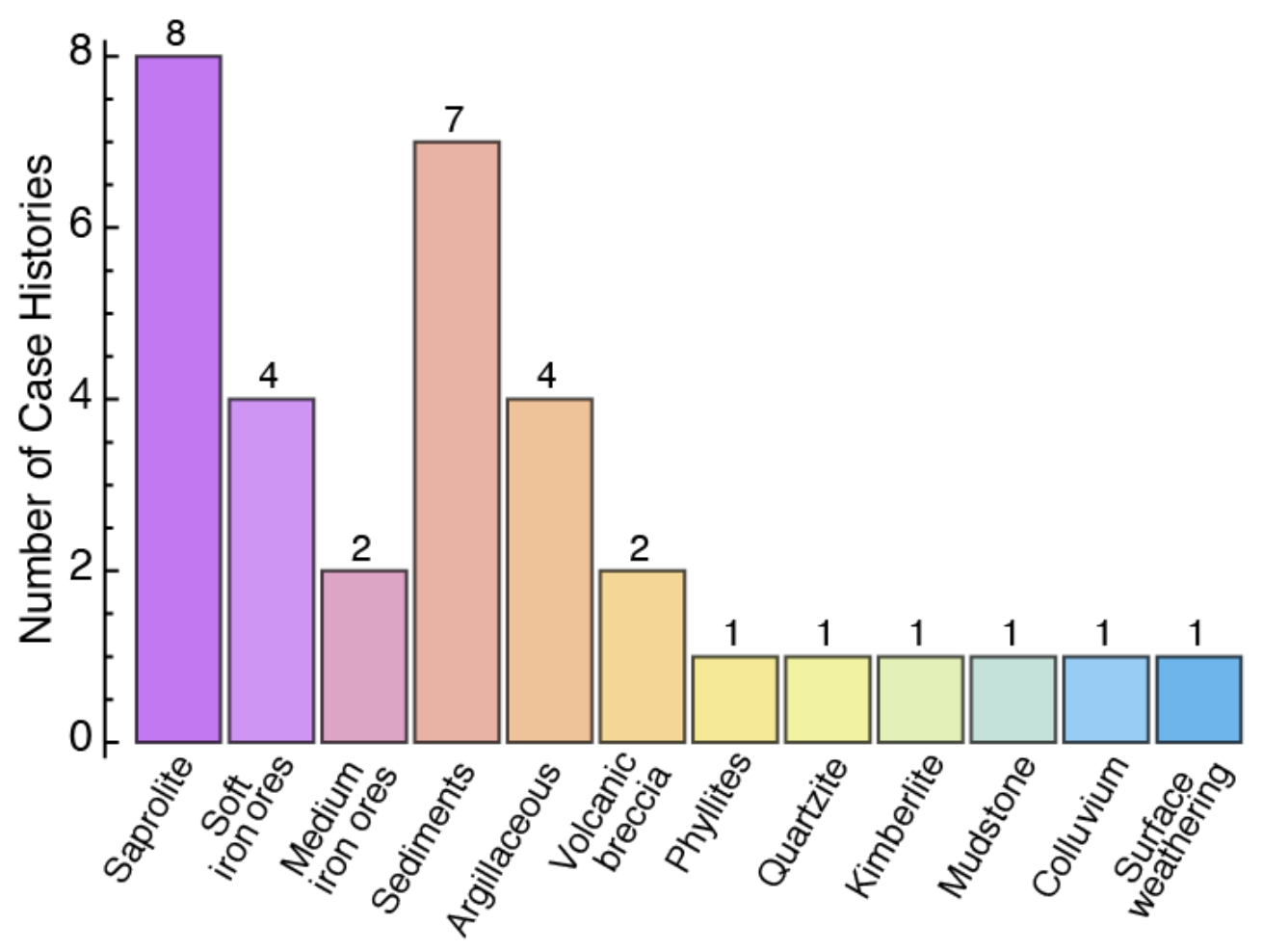

Figure 1 Pit wall instabilities reported by the mining industry and categorised by geology

\section{$2 \quad$ General descriptions and definitions}

The term weak rocks in the International Society for Rock Mechanics (ISRM) Classification ranges from extremely weak (R0) to weak (R2), with associated uniaxial compressive strengths ranging from $250 \mathrm{kPa}$ to $25 \mathrm{MPa}$, respectively (Figure 2). The R0 class overlaps with soils that display very stiff (S5) to hard (S6) characteristics. Consequently, slope failures in pit walls excavated in weak rocks can display behaviours ranging from those associated with stiff soils to slope failures partially controlled by discrete geological structures. For this LOP project the term weak rocks is used to recognise both the weak rock strength and soil like behaviour observed in the pit slope failures given in Figure 1.

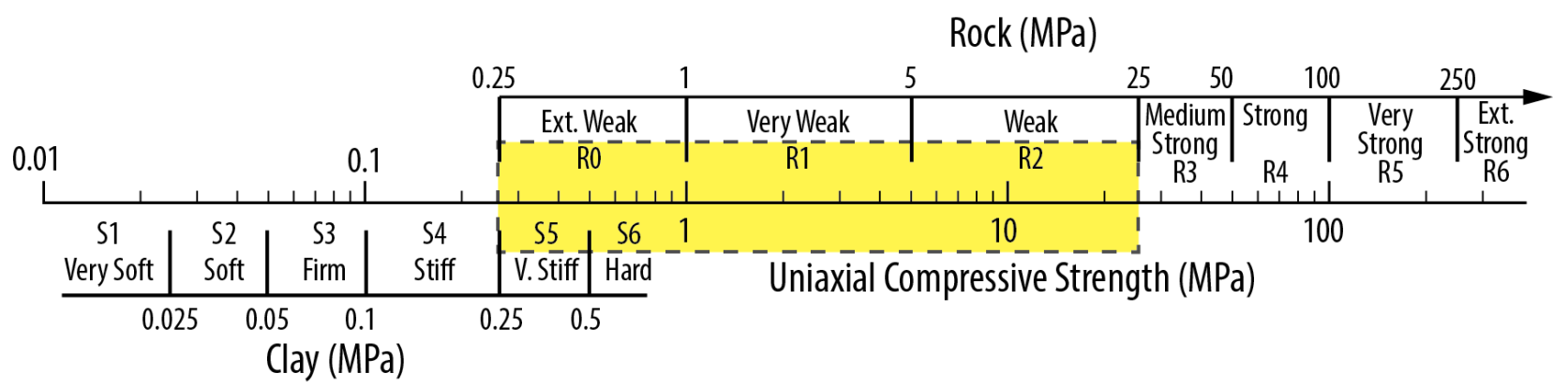

Figure 2 Range of uniaxial compressive strength typically associated with 'weak rock' ge ology described in this report (ISRM Suggested Methods, Brown, 1981)

Grouping of the results in Figure 1 resulted in five general weak rock categories that will be addressed by the Guidelines for Open Pit Slope Design in Weak Rocks, namely: (1) cemented transported sediments, (2) saprolites (residual soils and weathered rocks); (3) leached rocks/soft iron ores (leached, creating a rock with a high void ratio); (4) mudrocks; and (5) hydrothermally altered rocks. These categories are illustrated in Figure 3 and described in the following sections. 


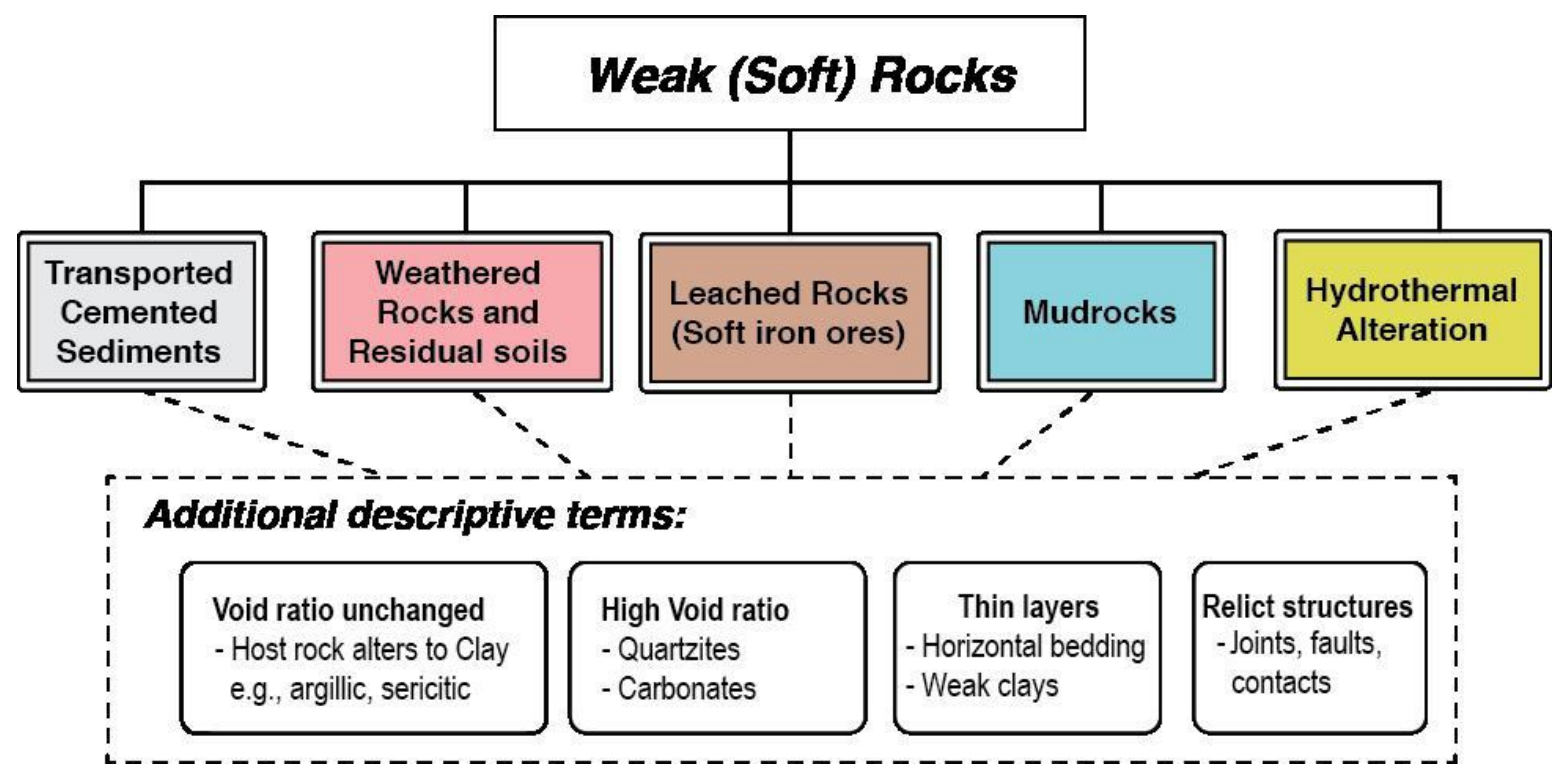

Figure 3 The five geology categories classed as weak rocks

\subsection{Cemented transported sediments}

Transported sediments are those that have been derived from material that has been transported from their original source and then deposited in layers by water or air (Figure 4). They are typically young and have no genetic relationship to the underlying bedrock and any associated residual soils. The transport and sorting aspect of these materials is what contrasts them to residual soils, which are formed in place. The transported sediments may be cemented or indurated and may show distinct layering and bedding, with the respective layers having significantly different mineralogy and material properties (Figure 4). It should be noted that very recent transported unconsolidated soils are specifically excluded from this weak rock category, because their behaviour is covered by traditional soil mechanics.

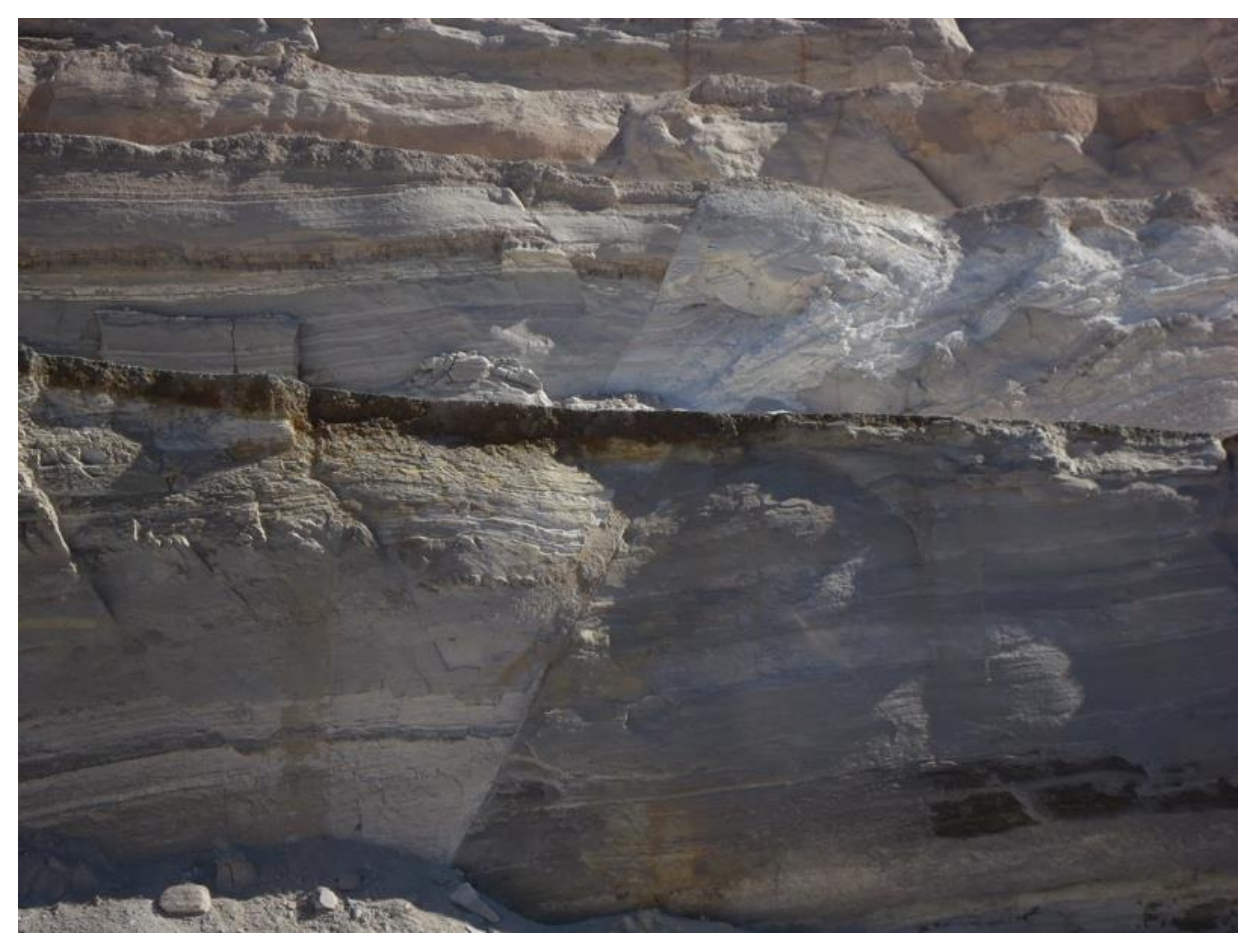

Figure 4 Photo of cemented transported sediments exposed in an open pit slope of PlioceneMiocene age Carlin Formation, northern Nevada (photo by R. Sharon) 
In a mining context, transported sediments typically form the initial materials that may be encountered when developing an open pit. They can range in thickness up to several hundred metres and can hence form a significant proportion of the pit slope, as shown (Figure 5).

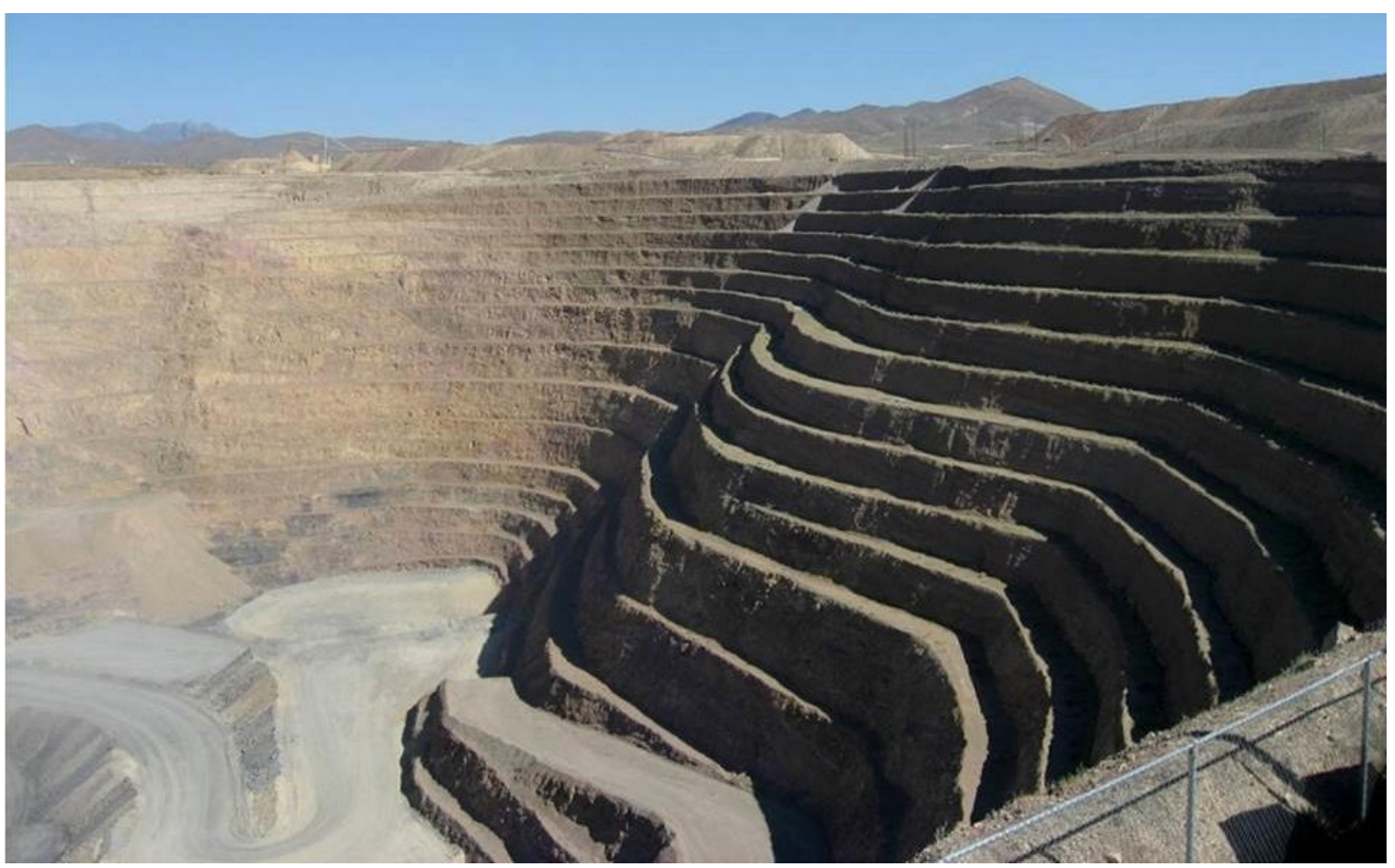

Figure 5 Photo of pit slopes in cemented colluvium Cortez, Nevada

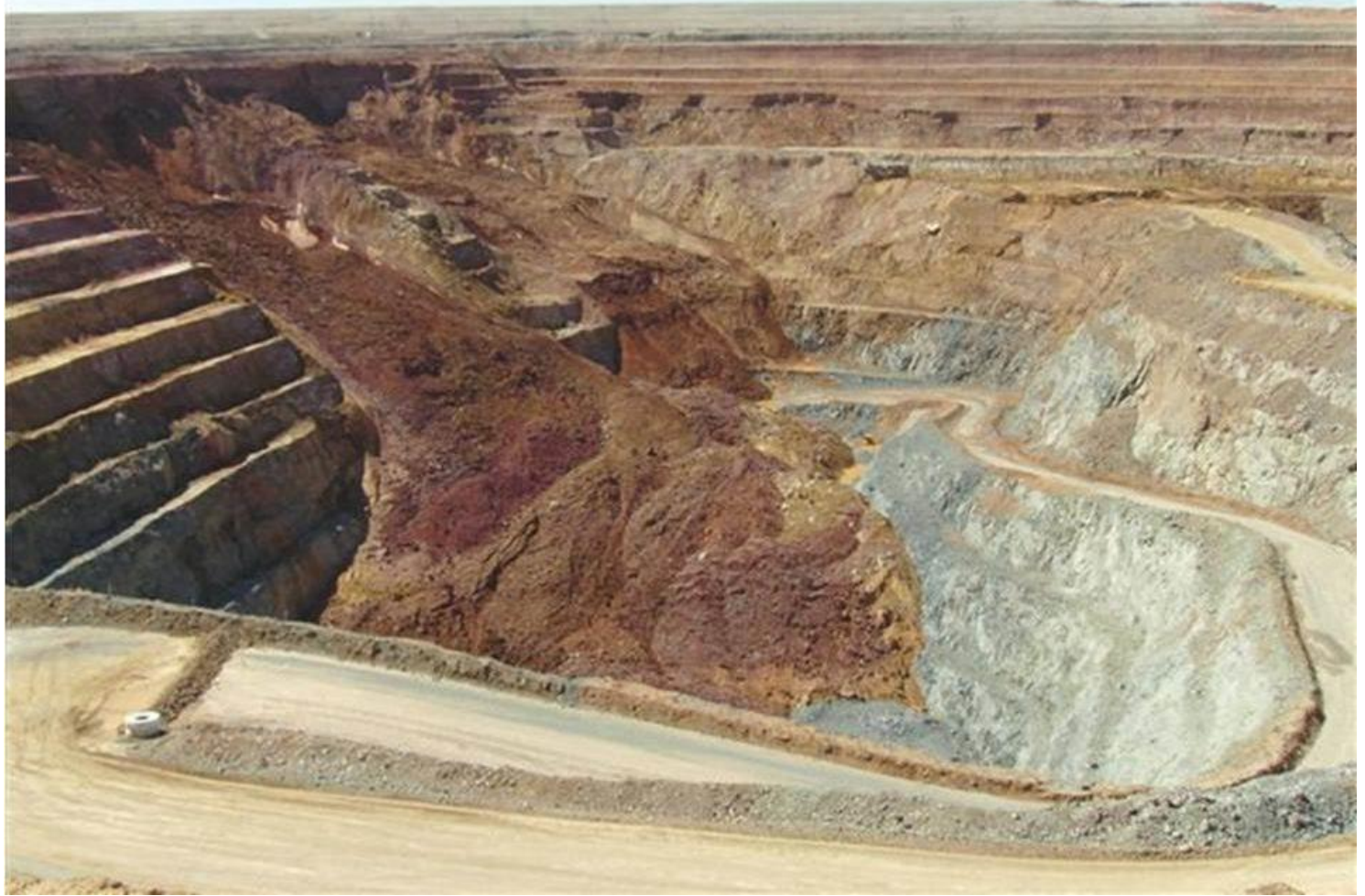

Figure 6 Flow slide of lakebed sediments and saprolite (photo by R. Sharon)

The term, transported sediments, covers a wide variety of materials and significant variations in properties. The cemented colluvial gravels exposed in several gold mines in Nevada are relatively strong and support 
slope angles of up to $60^{\circ}$ over heights of up to at least $200 \mathrm{~m}$, as shown (Figure 5). Inspection of Figures 4 and 5 suggests these materials must have significant cohesion, but because of their transported soil origin also have a relatively high porosity compared to most rocks. Consequently, these materials will remain stable as long as the cohesion remains undisturbed. On the other hand, fine-grained lakebed sediments that are weakly indurated to the extent that they can be considered to have 'rock like' properties can be susceptible to either block sliding on weak planes or mass failures. The lakebed depositional history implies that the layering may have extensive aerial extent. Hence, slope failures controlled by these weak layers can be extensive. These materials can also fail as flow slides if saturated, with the potential for collapse mechanisms and static liquefaction (Figure 6).

In these materials there is a need for a complete understanding of the geologic setting of the cemented sediments as the primary 'bad actor' for pit walls may be faults (Figure 4) and weak bedding planes with adverse orientation. There may also be the potential for collapse of cemented soils if the cementing agent is water soluble and an external water source is applied to the pit wall (leaky tails dam, reservoirs, pipelines). Understanding of the cementing agent (calcium carbonate, gypsum, or iron oxide) could be very important to pit slope design in these materials

\subsection{Saprolites: residual soil and weathered rock}

In contrast to the cemented transported sediments, saprolites (residual soil and weathered rock) are derived from in situ weathering and decomposition of rock by interacting physical and chemical (including biological) processes. Weathering results in the formation of a vertical profile, represented by a succession of zones (horizons) having differing chemical, mineralogical and/or physical characteristics. As the parent rock weathers, its original fabric is initially retained, but new fabrics develop in upper horizons by collapse, consolidation and the formation of secondary structures. In extreme cases the original fabric may be totally destroyed and the mineralogy completely changed.

In temperate regions, mature soil profiles $1-2 \mathrm{~m}$ deep have developed within the last 10,000 years, i.e. since the last glaciation. In stable continental regions, profiles ranging from as little as $3 \mathrm{~m}$ to in excess of $100 \mathrm{~m}$ have developed over periods of millions to tens of millions of years, generally under humid sub-tropical to tropical climates. These deep weathering profiles are the most significant in an engineering context. They consist of materials having a wide range of compositions and physical properties, depending on the original bedrock lithology, weathering processes and weathering history. This heterogeneity, varying from soil to unweathered rock, can present significant challenges to slope designers and pit operators. Deere and Patton (1971) gave an excellent description of residual soil and weathered rock and emphasised that the key to understanding the stability of slopes in residual soils lies in recognising the roles of weathering profiles, groundwater, and relict structures. Figure 7 shows the general description of residual soil and weathered rock proposed by Deere and Patton (1971), with the nomenclature that was proposed by the Tropical Residual Soils Geological Society Engineering Group Working Party Report (Fookes, 1990).

As illustrated in Figure 7, the structure of the parent rock, which is generally referred to as 'relict structures', becomes more important with depth as the behaviour becomes more rock like. Hence the challenge with residual soils and weathered rock is developing methodology for describing this heterogeneous soil and rock behaviour. The seminal work by the Geological Society Engineering Group Working Party Report on Tropical Residual Soils provides a comprehensive summary of the engineering behaviour of residual soils (Fookes, 1990). This work was supplemented by a description and classification of weathered rocks for engineering purposes in 1995, (Norbury et al., 1995). The bases for the findings given in these papers were strongly influenced by civil engineering work in Hong Kong, first summarised by Lumb (1975). This work highlighted the importance of soil suction (negative pore pressures) in the stability of partially saturated soils. While this is relevant in the stability of shallow slopes where the behaviour is dominated by the residual soil portion, its importance is reduced as the proportion of weathered rock increases. The recent work by Hencher and Lee (2010) compiled the experience with the slopes in Hong Kong and presents a comprehensive approach to characterising weathered igneous rocks. 

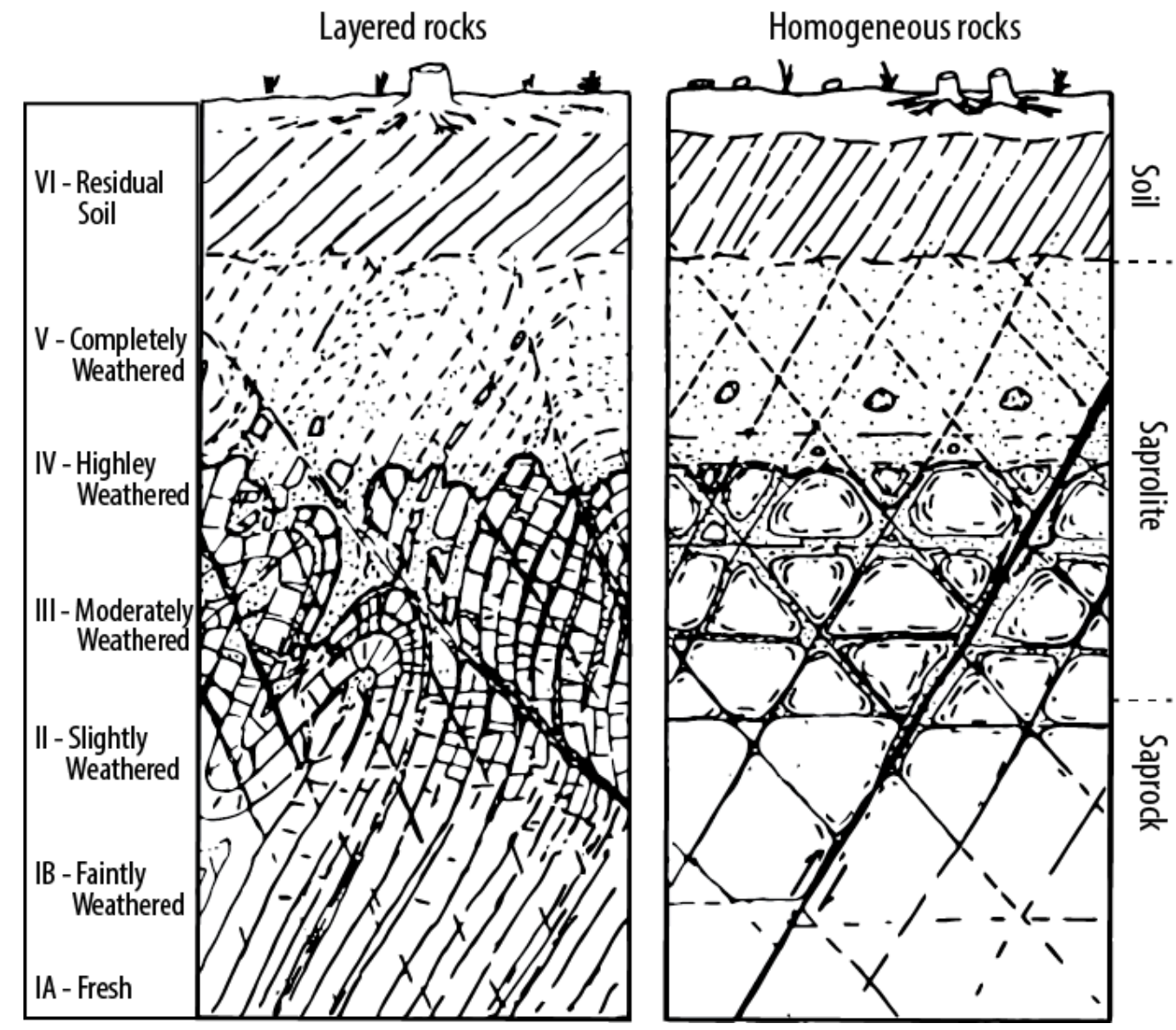

Figure 7 Generalised illustration of residual soils and weathered rocks (modified from Deere and Patton, 1971)

In the completely weathered form structure and fabric are destroyed, and the mineralogy can be significantly changed, typically to clays. For these materials understanding the degree of plasticity and the clay mineralogy is particularly important. In this regard, the use of Casagrande's Plasticity Chart shown in Figure 8 , as well as x-ray diffraction (XRD) can be particularly useful. The minerals often encountered in residual soils are summarised in Table 1 , and the location of these soils on Casagrande's Plasticity Chart is also illustrated in Figure 8. The primary function of this chart is to enable comparison of similar soils so that behaviour can be quantified based on previous experience. Wesley (2010) provides an overview of the challenges that can be encountered when using the Plasticity Chart to classify residual soils.

Table 1 Distinctive residual soil groups in terms of engineering behaviour (after Wesley, 2010)

\begin{tabular}{|c|c|c|}
\hline Commonly Used Names & Dominant Clay Mineral & Important Characteristics \\
\hline $\begin{array}{l}\text { Lateritic soils } \\
\text { Tropical red clays }\end{array}$ & $\begin{array}{l}\text { Halloysite, Kaolinite, } \\
\text { Gibbsite, Goethite }\end{array}$ & $\begin{array}{l}\text { Very large group with wide variation in } \\
\text { characteristics, engineering properties } \\
\text { generally good }\end{array}$ \\
\hline $\begin{array}{l}\text { Volcanic ash soils } \\
\text { Andosols }\end{array}$ & $\begin{array}{l}\text { Allophane and minor } \\
\text { Halloysite }\end{array}$ & $\begin{array}{l}\text { Characterised by very high water content } \\
\text { and irreversible changes when dried }\end{array}$ \\
\hline $\begin{array}{l}\text { Black cotton soils } \\
\text { Black clays }\end{array}$ & $\begin{array}{l}\text { Smectite } \\
\text { (Montmorillonite) }\end{array}$ & $\begin{array}{l}\text { Problem soils, high shrinkage and swell, } \\
\text { low shear strength }\end{array}$ \\
\hline $\begin{array}{l}\text { Tropical black earths } \\
\text { Grumusols }\end{array}$ & & \\
\hline
\end{tabular}




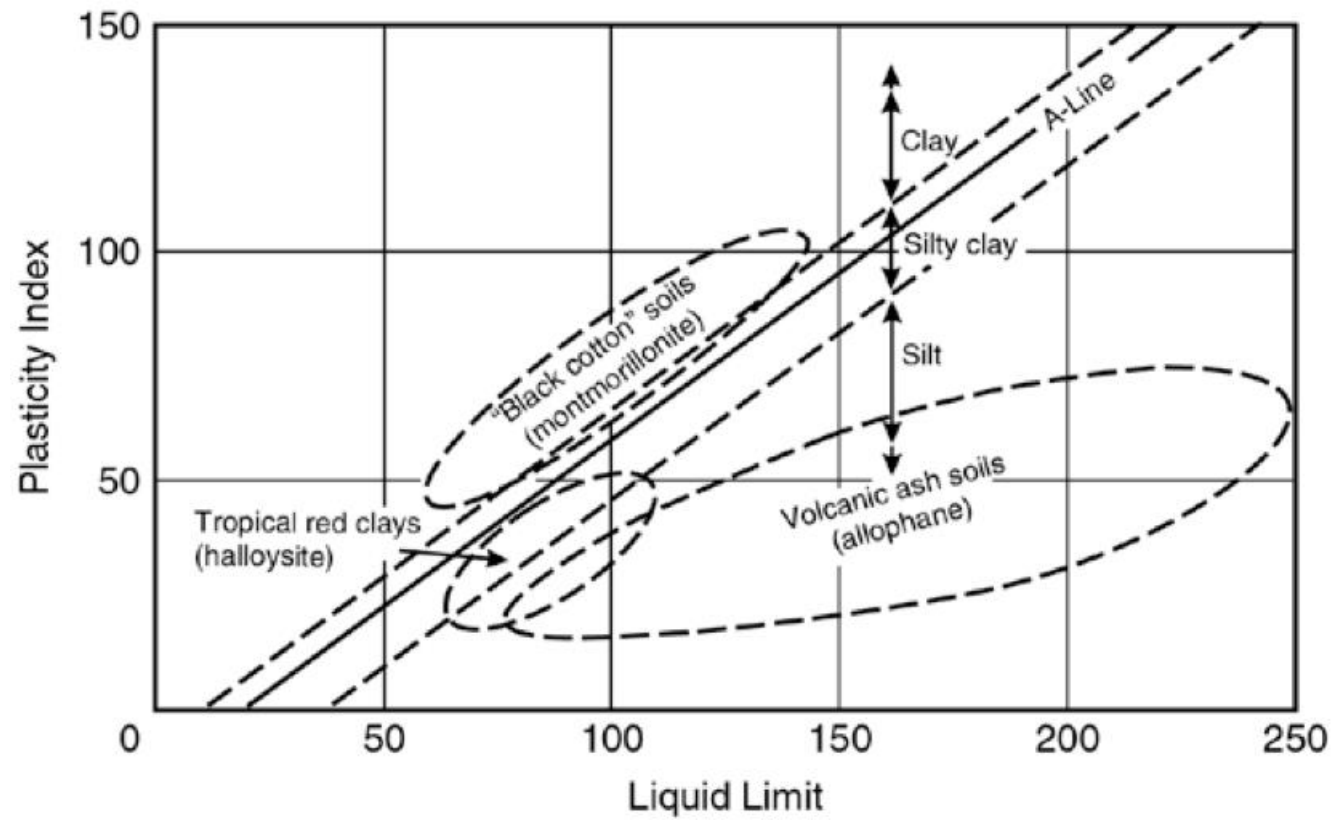

Figure 8 Conventional Casagrande Plasticity Chart showing several tropical residual soils (after Wesley, 2010)

In open pit operations the 'soil-like' behaviour that can be encountered when mining the more highly weathered rock is illustrated in Figure 9. Although mechanical excavation of the slopes may be straightforward in these materials, characterising them, and establishing their short and long-term behaviour as a basis for slope designs, remains challenging.

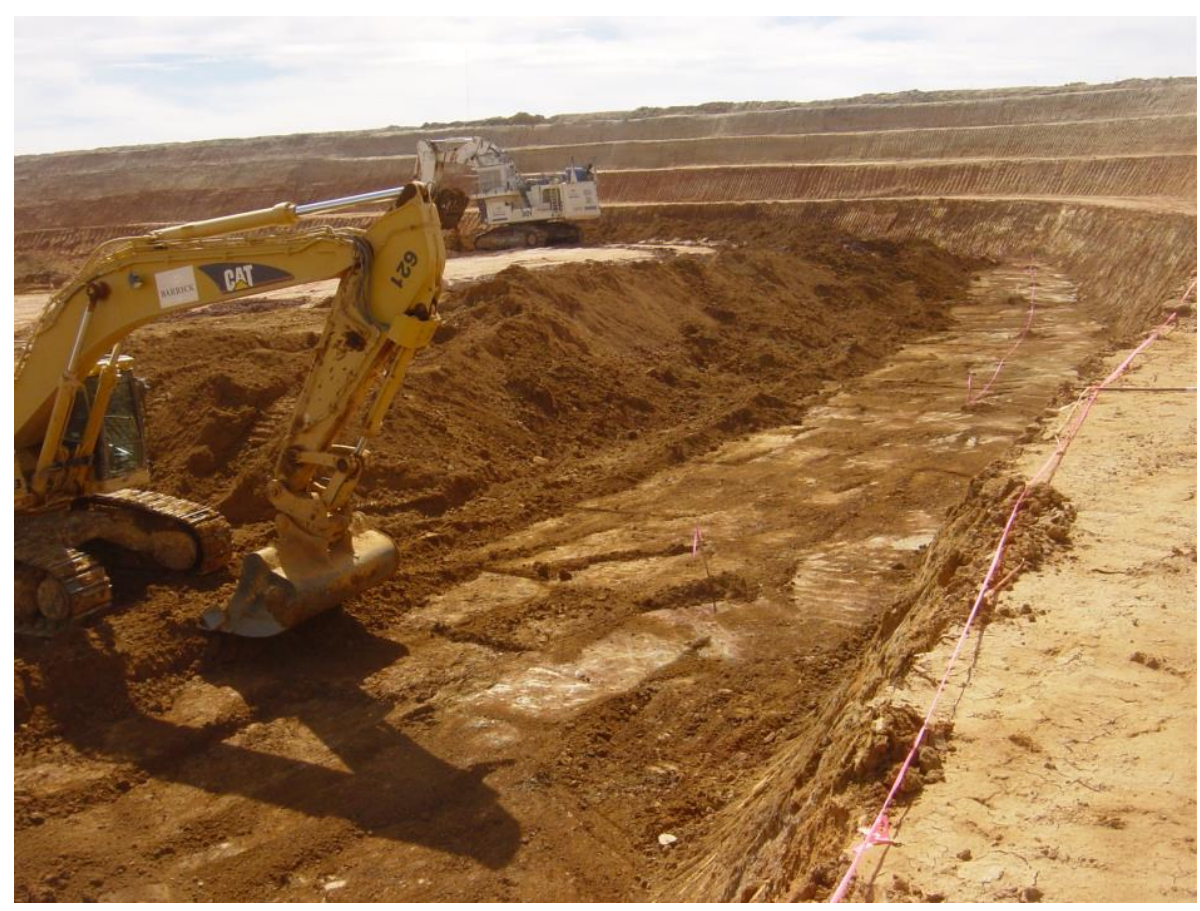

Figure 9 Example of open pit mining in weathered rock and residual soil. At this depth the material is excavated and treated as a soil (photo by R. Sharon)

Saprolitic materials can frequently be excavated without blasting and steep bench faces can be achieved using either excavators or through dozing, as shown (Figure 10). The steep faces can have a significant advantage in tropical climates, since they promote rainfall runoff and minimises surface area exposed to 
erosion. However this approach requires a robust surface water management strategy to prevent concentrated flows which can result in severe erosion of these weak materials (Beale and Read, 2013).

In less weathered saprolites the relict structure and fabric of the rock mass introduces anisotropy. It is not uncommon for the weathering front to follow the original rock structure so that the vertical depth of weathering can vary significantly. In these situations the weathering reduces the rock mass strength and the strength of the discontinuities.

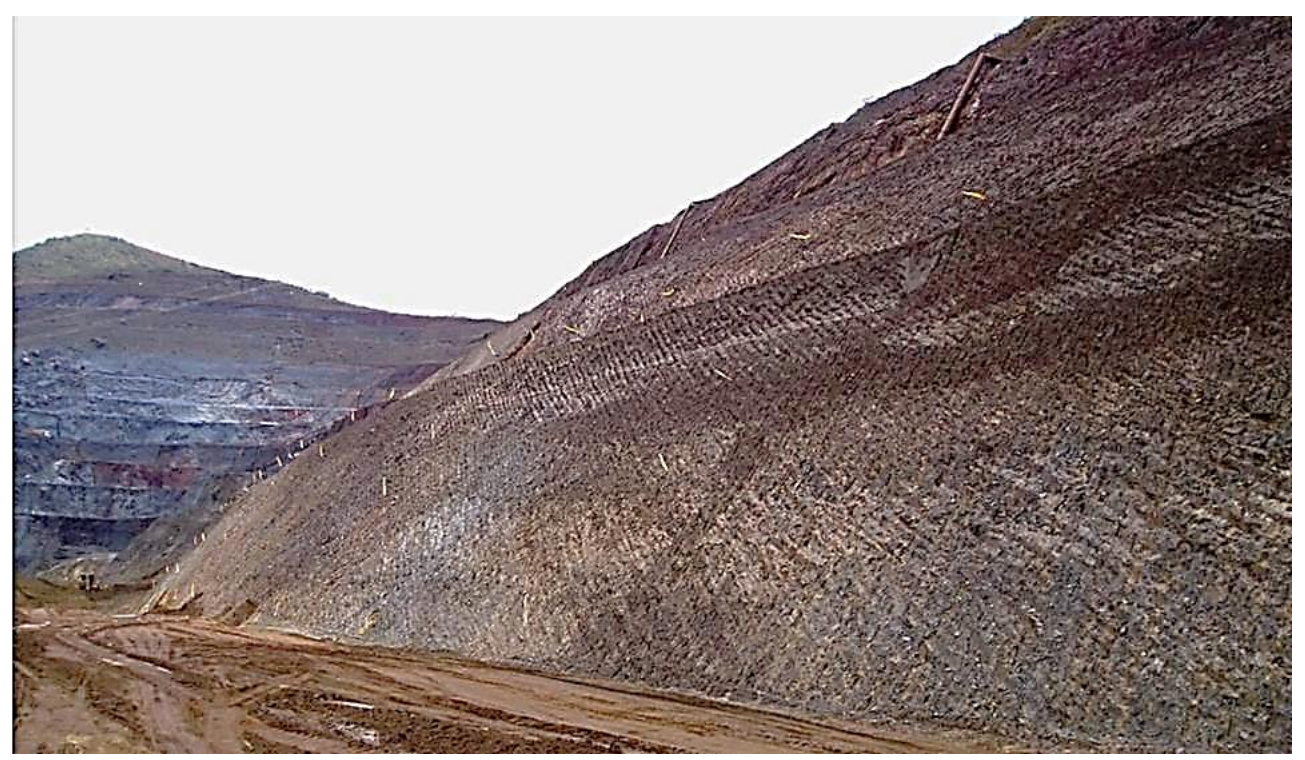

Figure 10 Dozer cut slope in saprolites in a Brazilian iron mine

\subsection{Leached rocks/soft iron ores}

Leached rocks are characterised by the removal of certain minerals by supergene or, less frequently, hypogene processes to form a material with a relatively high void ratio. Probably the most prolific material of this type found in open pit mines is the soft iron ores resulting from the leaching of Precambrian banded iron ores (itabirites), but other examples can be found in leached quartzites, in saprolites and in 'vuggy silica' alteration zones associated with some hydrothermal gold deposits. Regardless of the process or the initial material, weakly cemented grains and a high porosity characterise the resulting leached material.

The friable variants of high grade iron ores (soft iron ores) formed by the leaching of Precambrian itabirites are found in large deposits in tropical countries, notably Brazil, Guinea and other West African countries. To a lesser extent they are also present in non-tropical countries including Canada and Australia. High grade iron ores resulting from the leaching of itabirites are given different local terms around the world, but can generally be classified as follows:

- Powder ore: totally disaggregated iron oxide grains.

- Friable ore: iron oxide grains cemented by either re-mobilised iron oxide or carbonate.

- Medium ore: a mixture of friable ore and compact ore.

- Compact ore: massive iron oxide.

Typically, the iron oxide is hematite or martite, often derived from oxidation of magnetite in the original itabirites.

The friable ores are generally associated with metamorphic sediments, phyllites and quartzites, or mafic rocks, which are also altered in the vicinity of the leached iron ores. The resulting rocks are typically weak to very weak, with ISRM values in the range of R0 to R1/R2. In extreme cases the alteration results in soil-like properties for the phyllites, but more generally they remain foliated, but with uniaxial compressive 
strengths of less than $5 \mathrm{MPa}$, and a clear strength anisotropy; this gives them similar characteristics to saprolites.

There have been several examples of pit slope failures in the soft iron ores in the iron Quadrangle in Minas Gerais state in Brazil, probably the most notable being the failure of the Patrimônio slope in the Águas Claras open pit in 1992. Since the Águas Claras failure, it has been recognised that particular attention must be focused on pit slopes in soft iron ores, which can extend to depths of several hundred metres. In many of the deeper pits the soft iron ore forms the lower section of walls and on occasion it is necessary to leave sections of soft iron ore on pit walls for economic reasons. It is therefore essential to have a full understanding of the strength characteristics of these materials when subjected to the stresses experienced in high pit slopes. This has been reinforced by other failures in the Brazilian iron ore open pits, most of which have involved some degree of structural control (sliding on foliation or on weak contacts within the country rock) combined with mass failure through the iron ore.

\subsubsection{Patrimônio slope in Águas Claras open pit}

The Patrimônio slope at the west end of the Águas Claras north wall was approximately $240 \mathrm{~m}$ high at the time of the failure in April 1992. It was composed of soft iron ore overlying medium strength itabirites, with a thin layer of silica-rich leached itabirite along the contact. The sequence was dipping towards the pit at an angle of approximately $42^{\circ}$ (da Franca, 1997).

The first evidence of instability was detected on April 8 in the form of a crack at the crest of the slope, with further cracks appearing a few days later in drainage ditches on the sides of the wall. On April 23 cracks were noted in the operating face and mining was suspended. The failure, which occurred on April 29, involved some 2 million tonnes of soft iron ore, which ran out approximately $500 \mathrm{~m}$ across the pit floor and buried the in-pit crusher at the toe of the opposite wall (Figure 11).

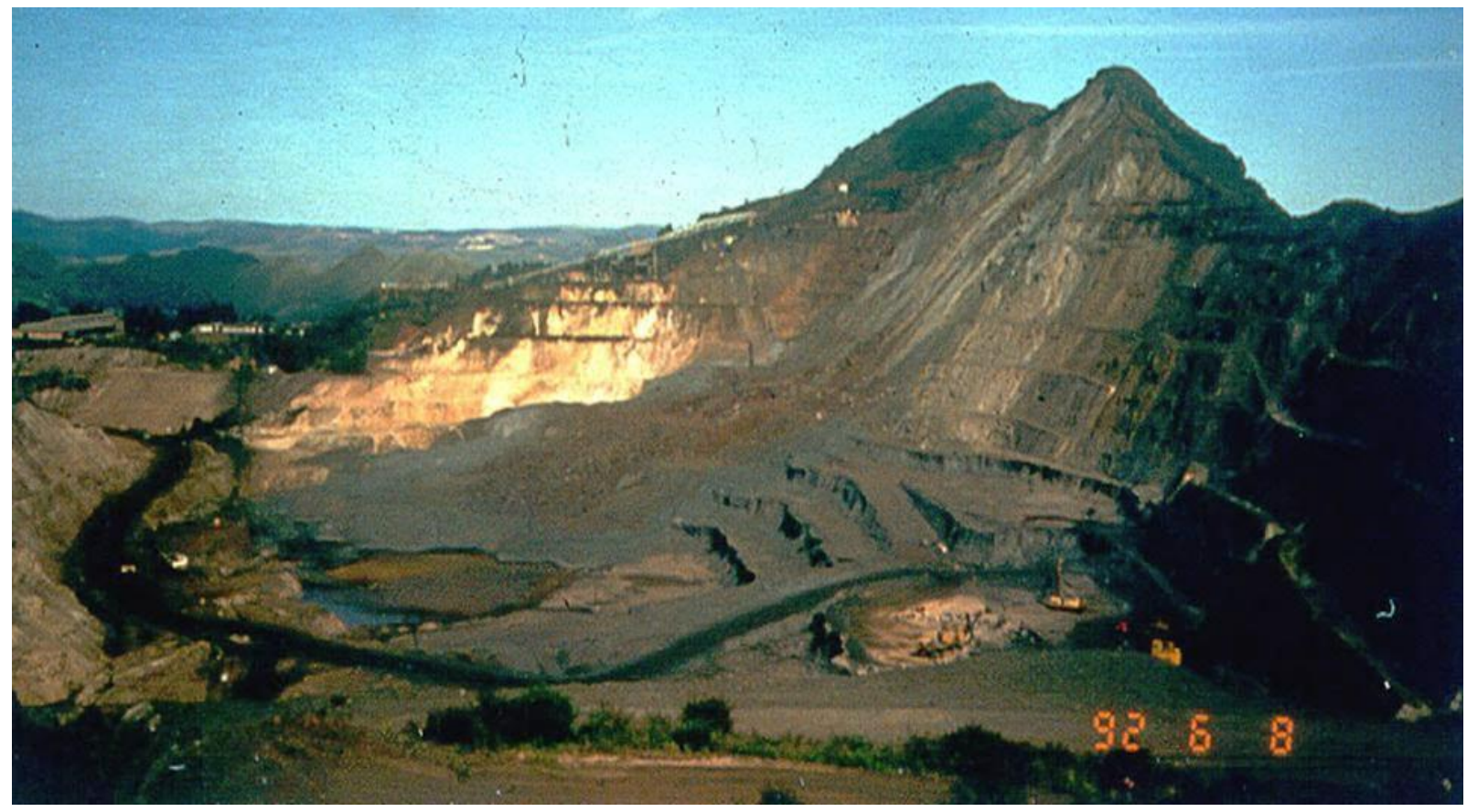

Figure 11 Photograph of a runout from the Patrimônio failure

Monitoring installed after the first crack was detected indicated a total, accelerating movement of only $7 \mathrm{~cm}$ until the failure occurred. It is therefore reasonable to assume that to the maximum displacement that occurred prior to failure was in the order of $15 \mathrm{~cm}$. The slope was completely drained.

The salient features of the failure can therefore be summarised as follows:

- Very little movement prior to failure. 
- Rapid development of the failure process.

- An extremely fast rate of failed debris.

- Long runout of disaggregated material.

- No involvement of water pressures.

Contributing factors to the failure were undoubtedly the convex shape of the wall, which was dictated by a requirement to protect the crest for heritage reasons, and the orientation of the foliation, which parallelled the slope. The rapid development of instability, accompanied by only limited displacement prior to an extremely rapid failure for the events described above, suggests a brittle form of failure characteristic of the 'collapsible' soils. The long run-out is symptomatic of what would be termed a 'debris avalanche'.

It is suggested that the initial failure mode involved a collapse of the structure of the leached iron ore, resulting from failure of the inter-granular bonds and the high void ratio. Work is still very much in progress to characterise the behaviour of these soft iron ores, but some of the findings can be summarised as follows (Costa, 2009):

- Petrographic work has identified at least three different types of friable iron ore from the Minas Gerais iron Quadrangle based on micro-texture. These are:

- Foliated - with a preferred orientation to the tabular hematite grains.

- Banded - interbanded granular and lamellar hematite.

- Brecciated - with clasts of hematite in a fine grained hematite matrix.

- Cementing material is either remobilised hematite or goethite.

- Inter-granular porosities can be greater than $20 \%$.

- UCS values are typically <2 MPa (R1 to RO - very weak rock).

- Peak shear strength derived from triaxial testing: $\varnothing=33^{\circ}, c=50-100 \mathrm{kPa}$.

- There is at least some degree of anisotropy, excluding natural discontinuities.

- Limited triaxial testing results show characteristics of brittle failure.

Further discussion of these characteristics is to be found in Section 3.2.

\subsection{Mudrocks (clay shales)}

The general geological definitions for the rocks found in this category of weak rocks are given by Potter et al. (2005) as:

- Mud, mudstone, mudshale and mudrock - 'Mud' is a field term for any soft plastic, silt-clay mixture with more than $50 \%$ of its size fraction smaller than four microns. The general generic term applies to fine-grained argillaceous rocks.

- Clay, claystone, and clay shale - A field term for a clay-rich, fine-grained, plastic sediment with little or no silt; a size fraction, all of which is finer than four microns.

- Shale - Originally applied to an indurated, laminated, fine-grained argillaceous rock, but also widely used as a broad term for the entire class of such rocks, laminated or not.

- Silt and siltstone - Both need at least 50 \% silt-sized material which typically can be easily determined in the field; silts are non-cohesive and non-plastic, but in some cases easily liquefy.

In the engineering community, the fine-grained argillaceous rocks (mudrocks) are generally referred to as clay shale. Figure 12 illustrates the typical behaviour of drill cores of clay shales when exposed to atmospheric moisture or desiccation. It is evident from that slake durability testing should be useful in 
characterising this class of materials. Grainger (1984) and more recently Santi (2006) have proposed extensive methods for characterising and classifying mudrocks for engineering purposes.

The characteristics and behaviour of this class of weak rock can be summarised as:

- Porosity $>4 \%$.

- Contains a high percentage of weak clay minerals.

- Strength a function of moisture content (Figure 13).

- Propensity to swell after unloading and exposure to moisture.

- Prone to slaking (behaviour sensitive to moisture).

- Difficult to obtain laboratory properties that are not disturbed.

- Contrasting layers of stiff and soft rocks can lead to progressive failure during unloading.

- Sensitivity to moisture and softening can lead to delayed failure.

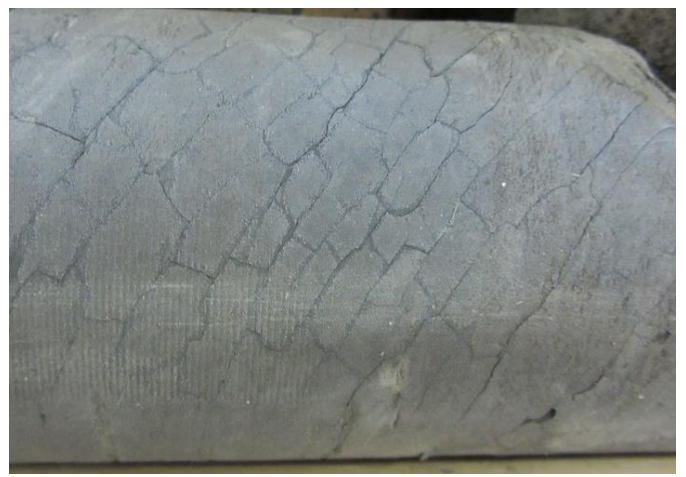

(a)

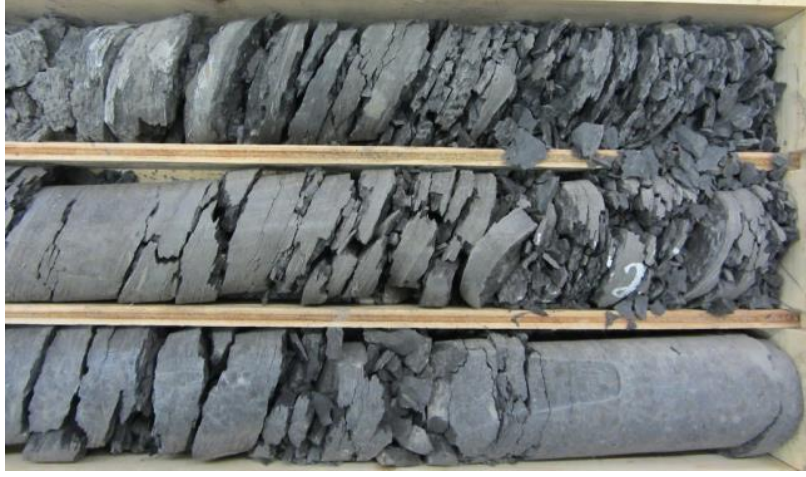

(b)

Figure 12 Typical behaviour of massive mudrock $\mathrm{HO}$ core when exposed to the atmospheric moisture; (a) initiation of the time-dependent process associated with moisture uptake; (b) massive intact core after seven days

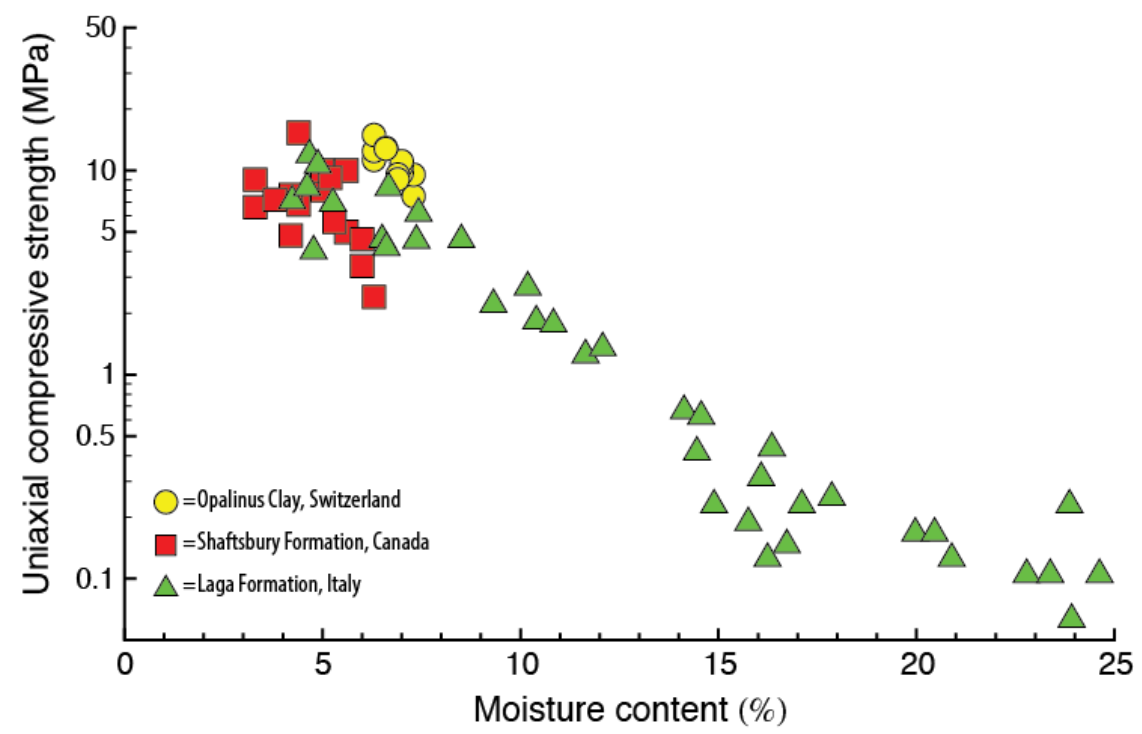

Figure 13 Effect of increasing moisture content on mudrock uniaxial compressive strength 


\subsubsection{Cobre Las Cruces open pit}

The Cobre Las Cruces open pit in Spain was excavated in mudrocks locally referred to as Guadalquivir Blue Marls. The pit is approximately 1,600 m long $\times 900 \mathrm{~m}$ wide $\times 250 \mathrm{~m}$ deep. Mineralisation is contained in the Paleozoic ore composed of volcanic and other metamorphic rocks underlying 120 to $150 \mathrm{~m}$ of Tertiary Guadalquivir Blue Marls. Cooper et al. (2011) describe the behaviour of these marls as that of overconsolidated clay. As is typical of mudrocks, bedding plane shears that developed as the pit was excavated control the stability of the excavated pit slopes. Figure 14 shows the discrete thin nature of the bedding plane shears exposed in the pit wall and the behaviour of the pit floor when the shears were located immediately below the operating bench.

Using an extensive monitoring program consisting of slope inclinometers and survey prisms, Cooper et al. (2011) concluded that the bedding planes were spaced every 3 to $7 \mathrm{~m}$ with an average spacing of $5 \mathrm{~m}$. They also show that the inclinometer data indicated the material above the bedding plane moved as a block. Back-analyses of the shear displacement showed that the operational bedding plane shear strength was $c^{\prime}=0.02 \mathrm{MPa}$ with $\phi^{\prime}=15^{\circ}$. These values are in contrast to the intact rock strength reported as $c^{\prime}$ ranging from 0.11 to $0.28 \mathrm{MPa}$ with the friction angle ranging from 18 to $22^{\circ}$.
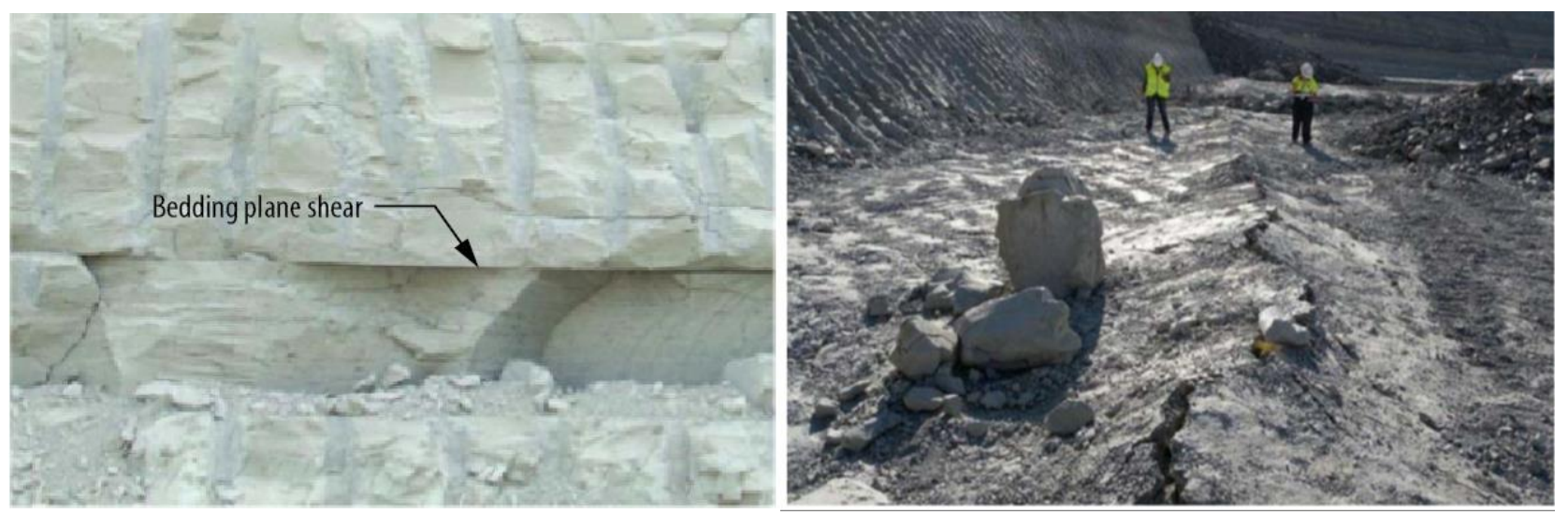

Figure 14 Example of the instabilities observed in the progressive failure along bedding planes in the Cobre Las Cruces open pit (photos from Cooper et al., 2011); (left) shearing of a bedding plane exposed in the pit wall; (right) shearing and buckling on bedding plane below the pit floor

\subsection{Hydrothermally altered rocks}

The alteration associated with intrusive or hydrothermal orebodies can result in a wide variety of changes to the host rock. The most dramatic and wide-ranging effects of hydrothermal alteration are on the intact rock and rock mass, in which the rock is chemically changed, with resulting different engineering behaviour characteristics. The main concern is with those changes resulting in rocks that have a strength of less than R2 in the ISRM scale. This typically involves argillic alteration because of the alteration to the weak clay minerals (Table 2).

\section{Table 2 Main types of alteration (after Watters and Delahaut, 1995)}

\begin{tabular}{ll}
\hline Alteration Type & Mineralogy \\
\hline Propylitic & Epidote and/or chlorite minerals \\
Intermediate argillic & Significant amounts of kaolinite, montmorillonite, and amorphous clay \\
Advanced argillic & $\begin{array}{l}\text { All feldspar minerals converted to dickite, kaolinite, alunite, and other } \\
\text { aluminium rich argillic phases }\end{array}$ \\
Sericitic & Potassium feldspar and plagioclase converted to sericite
\end{tabular}


Potassic

Silicic

Greisen

Fenite
Potassium feldspar and/or biotite formed as an alteration of mafic minerals Proportion of quartz or opaline silica increased

Similar to advanced argillic with more sericite or muscovite

Occurs around carbonatite intrusions and represents sodium metasomatism with hydrous silicates and hematite

Alteration associated with hydrothermal deposits can be highly variable and can either decrease or increase the strength of the host rocks (Figure 15). Argillic alteration almost invariably significantly reduces the strength of the original rock, destroying any structural fabric in the rock. This strength reduction is associated with the clay minerals, which can range from kaolinite and illite to montmorillonite. As a result, shear strengths can be rather variable with friction angles ranging from as low as 8 to $14^{\circ}$, and variable cohesion. Hence there is a need to classify the argillic alteration both in terms of mineralogy and degree so that those areas with the clay minerals can be identified and treated appropriately. Even with intense alteration, relict structures can also play a significant role is pit slope stability.

The clay mineralogy associated with the argillic alteration also results in very low permeability. Sullivan (2007) and, more recently Beale and Read (2013), reviewed the hydromechanical coupling in pit slopes, and note that this coupling becomes more important in altered rocks in which the low permeabilities almost invariably prevent rapid depressurisation by normal means. Horizontal drain holes tend to be less effective due to the fact that they cannot be installed until the slope has been excavated, and pumping wells normally show low effectiveness. Consequently, most slopes in argillic altered materials have to be designed assuming high pore pressures, for which remediation options are limited.

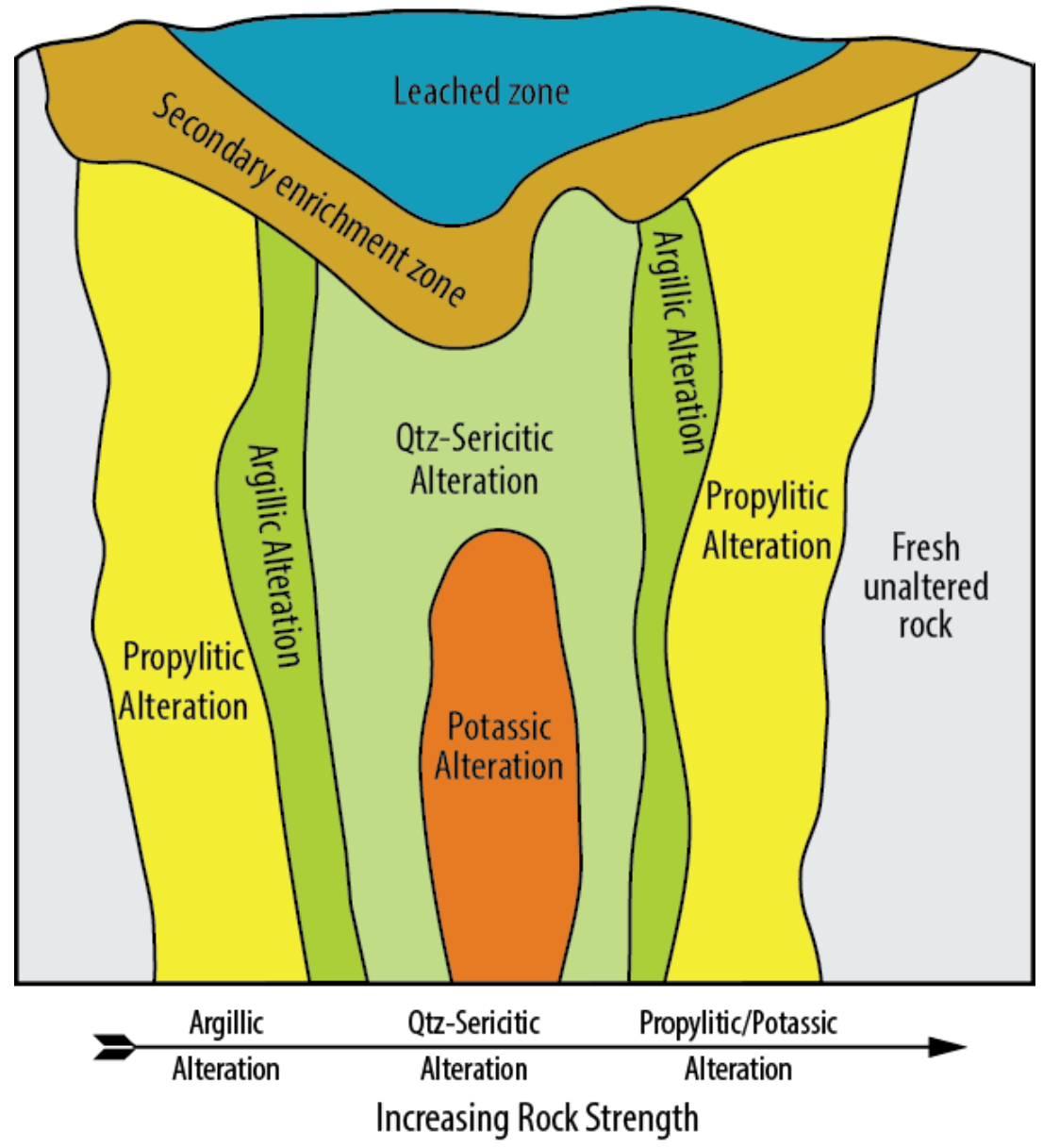

Figure 15 Common hydrothermal alteration halos and surface weathering associated with porphyry copper deposits, modified from Karzulovic (unknown source) 


\subsubsection{Lihir Gold Mine open pit}

Lihir Gold Mine is located on Lihir Island in New Ireland Province, Papua New Guinea and has been actively mined for gold by open pit since 1997. The local geology consists of a wide variety of volcaniclastic rock types including breccia, tuff, lahar and lava flows. However, classification of rock types for mining and geotechnical purposes is based on 'ore type' which takes into account properties such as alteration, hardness, degree of brecciation and mineralogy. The geotechnical behaviours of these ore types are heavily influenced by the weathering and alteration. The argillic alteration is the most widespread and is characterised by the clay minerals illite, smectite and kaolinite. Generally the original rock fabric is partially to completely destroyed.

Argillic material exhibits a considerable range in strength. Field estimated strength ranges from soil strength (S1-S5) at the lower end to R3 rock strength at the upper end. For geotechnical purposes it has been subdivided into two units on the basis of strength:

- Upper Argillic - largely soil strength (S1-S5 and RO).

- Lower Argillic - highly altered rock (RO-R3).

Tension cracking around the GW28 steam production well was first noted in October 2007, and associated with mining of a pushback immediately below (Figure 16). A rock mass failure progressively developed. The geotechnical investigation and back-analysis of the failure resulted in modification of the wall design. The design change comprised a small cutback at the crest, mining out GW28; and leaving a $30 \mathrm{~m}$ wide buttress at the $956 \mathrm{mRL}$ level. Despite the successful implementation of this first remediation step, further instability developed in early 2009 as the rock mass continued to deteriorate. A second small cutback was undertaken at the crest but was limited by the presence of the steam line at the crest that carried a significant percentage of total steam production at the time.

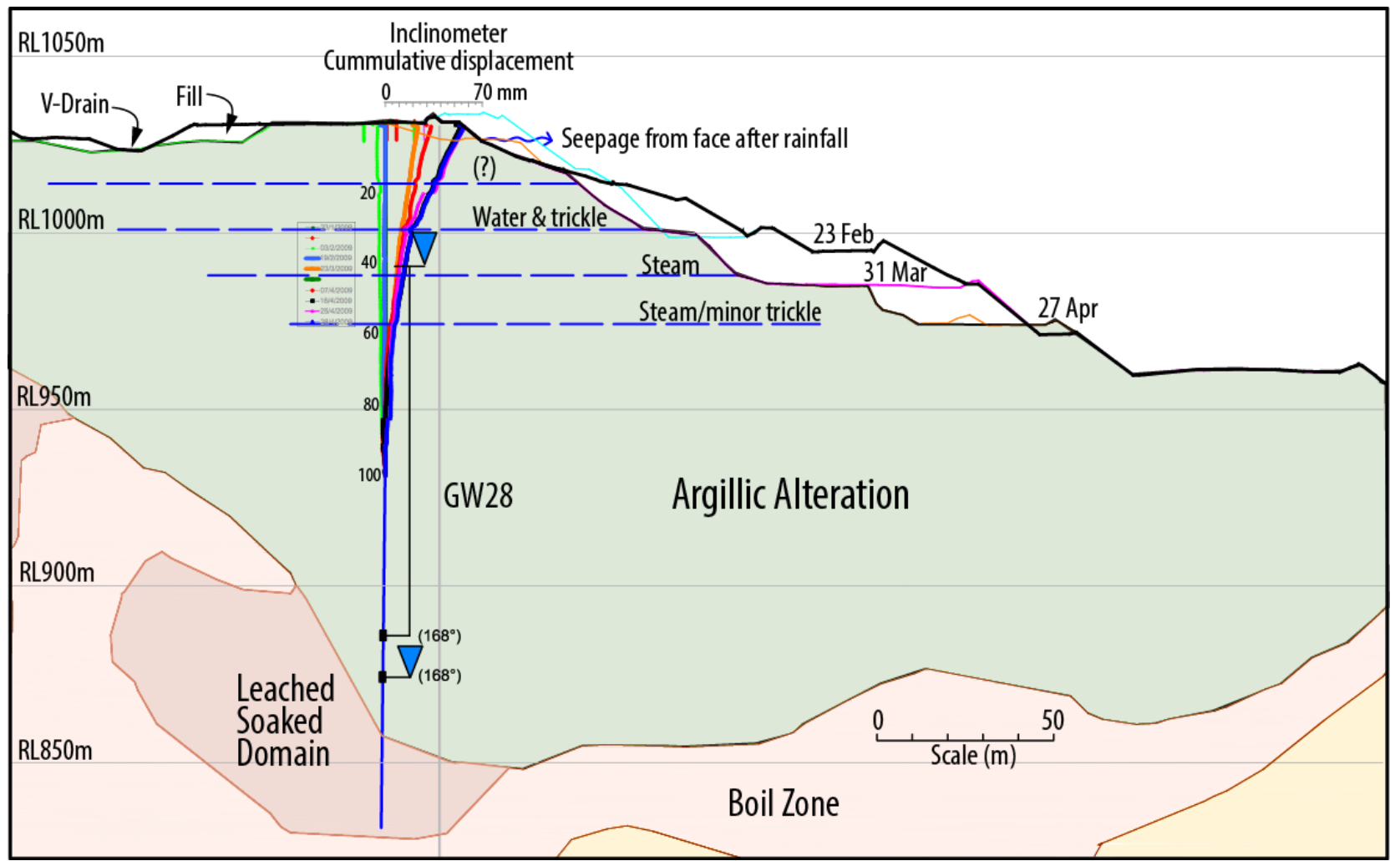

Figure 16 Instability in the Argillic alteration, locally referred to as GW28 slope

An inclinometer installed at the crest of the slope near GW28 showed gradual movement to a depth of about $70 \mathrm{~m}$. Over the monitoring period of 95 days, approximately $60 \mathrm{~mm}$ of movement was recorded, giving a movement rate of $<1 \mathrm{~mm}$ day (Figure 16). Back-analysis of the failed slope in the upper Argillic unit, 
assuming a water table near the ground surface, gave $c^{\prime}=45 \mathrm{kPa}$ and $\Phi^{\prime}=25^{\circ}$. Design parameters for the Lower Argillic units were assessed to be $c^{\prime}=90 \mathrm{kPa}$ and $\Phi^{\prime}=30^{\circ}$, reflecting the slightly better rock mass quality.

Figure 17 shows the ongoing condition of the GW28 slope in September 2010. Local movement picked up by the surface prisms indicate deformation rates of $>5 \mathrm{~mm} /$ day.
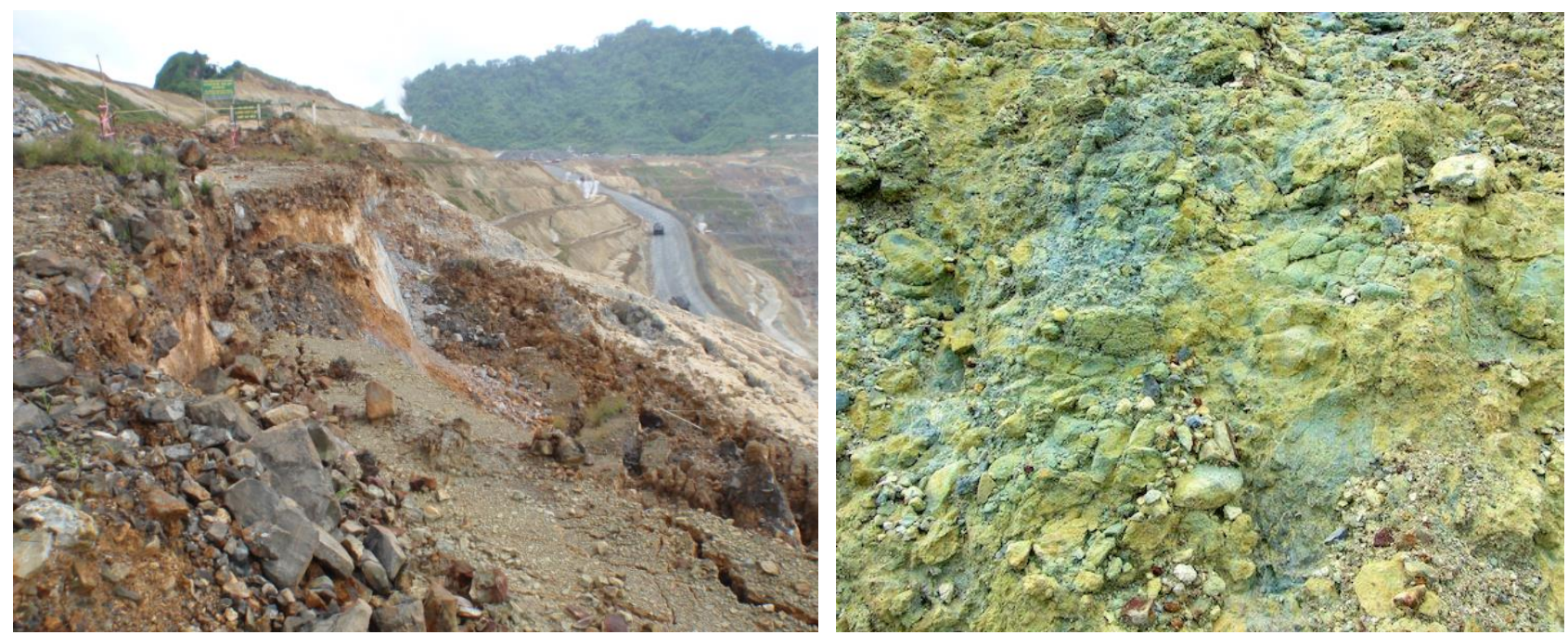

Figure 17 Photo (left) of the GW28 area taken in September 2010, showing the ongoing
instability in the Argillic Unit, and photo (right) of upper argillic alteration

One of the challenges at Lihir is the pore pressures in the Argillic unit. Figure 16 shows the hydraulic head measured by two vibrating wire piezometers. The lower piezometer reflects the heads associated with the Boil Zone, and illustrates the effectiveness of the Boil Zone as a drain. However the upper piezometer shows the increase in head associated with the argillic alteration. This is routinely observed at Lihir. Despite the efforts to drain the slope and the effective underdrain provided by the relatively high permeability Boil Zone, pore pressures in the Argillic unit remain high.

\section{Design considerations and instability mechanisms}

The descriptions given in previous sections highlight the characteristics of weak rocks that can potentially lead to issues for slope designers and pit operators. It is clear from these descriptions that the behaviour of these weak rocks results in slope performance that may differ from slopes in hard rocks. Table 3 summarises the primary characteristics of each weak rock type that can influence pit slope behaviour.

The Guidelines for Open Pit Slope Design (Read and Stacey, 2009) describe in detail the design process. One of the key elements is the geotechnical model, which is developed using four component models:

- The geological model.

- The structural model.

- The rock mass model (material properties).

- The hydrogeological model.

When developing the geotechnical model it is necessary to consider possible failure modes to ensure geotechnical processes are identified. The term 'process modelling' is currently used in many disciplines. Rolland (1998) suggested that an effective process model in any field should provide a means of communicating complex functions in a form understandable to practitioners in a standardised and repeatable manner, so that possible outcomes can be compared and contrasted. To develop such a model requires a complete understanding of the process. 
Process models in geotechnical engineering have five main components:

1. Generalised description of the process.

2. Knowledge of the physics that control the process.

3. Evaluation of possible outcome.

4. Calibration of the process and outcome with historical data.

5. Assessment of the outcome and communication of the risk.

In the following sections we highlight the geotechnical characteristics that should be considered when developing a process model for pit slopes in weak rocks.

Table 3 General ground types encompassed by the term weak rocks and characteristics that influence the behaviour of pit slopes

\begin{tabular}{|c|c|c|}
\hline Ground Type & $\begin{array}{l}\text { Geological } \\
\text { Characteristics }\end{array}$ & Slope Behaviour Typically Influenced By \\
\hline $\begin{array}{l}\text { Transported } \\
\text { sediments }\end{array}$ & Cemented layered soils & $\begin{array}{l}\text { Strength of cementing } \\
\text { Grain size } \\
\text { Weak layers } \\
\text { Cohesion loss }\end{array}$ \\
\hline $\begin{array}{l}\text { Saprolites } \\
\text { Weathered rocks }\end{array}$ & $\begin{array}{l}\text { Physical and chemical } \\
\text { weathering }\end{array}$ & $\begin{array}{l}\text { Unsaturated soils, high porosity } \\
\text { Collapsible micro-structure } \\
\text { Heterogeneous soils/rocks } \\
\text { Relict structures }\end{array}$ \\
\hline $\begin{array}{l}\text { Soft iron ores } \\
\text { Leached quartzites } \\
\text { Decalcified } \\
\text { limestones/marbles }\end{array}$ & $\begin{array}{l}\text { Chemical leaching } \\
\text { Phyllitic }\end{array}$ & $\begin{array}{l}\text { High porosity } \\
\text { Collapsible micro-structure } \\
\text { (Strength anisotropy) }\end{array}$ \\
\hline Mudrocks & $\begin{array}{l}\text { Contrasting layers of } \\
\text { argillaceous minerals } \\
\text { Low permeability }\end{array}$ & $\begin{array}{l}\text { Weak layers with low frictional resistance } \\
\text { Total stress and undrained pore pressure } \\
\text { response } \\
\text { Time-dependent processes - cohesion } \\
\text { loss } \\
\text { Progressive failure }\end{array}$ \\
\hline $\begin{array}{l}\text { Hydrothermal } \\
\text { alteration }\end{array}$ & $\begin{array}{l}\text { Argillic } \\
\text { Sericitic } \\
\text { Low permeability }\end{array}$ & $\begin{array}{l}\text { Heterogeneous soils/rocks } \\
\text { Weak clay minerals, including kaolinite, } \\
\text { smectite, illite, sericite } \\
\text { Total stress and undrained pore pressure } \\
\text { response }\end{array}$ \\
\hline
\end{tabular}

Note: Pore pressures likely plays a significant role in slope behaviour in all weak rocks.

\subsection{Rock mass strength}

A key step in a slope design is defining the processes that should be considered when attempting to establish the strength and failure envelopes for an open pit in weak rocks. While the strength of hard rocks is traditionally established using empirical approaches, there is ample evidence that these approaches are not capturing the failure processes evident in weak rocks. 
Estimating rock mass strength in open pit practice is dominated today by the Hoek-Brown failure criterion and the Geological Strength Index (GSI), (Hoek et al., 2002; Marinos and Hoek, 2000). Hoek has routinely cautioned users of the application of the methodology to weak rock masses, particularly when GSI values are 25 or lower. The Hoek-Brown GSI approach was developed for a tightly interlocked rock mass with a minimum of three joint sets and relatively low porosity of the intact material. Hoek (pers. comm., 2013) states:

"In general I consider that GSI is only applicable to rock masses in which the strength depends, to a very significant degree, upon particle or block interlocking. Hence it should not be applied to transported materials such as sands, gravels and waste rock where the original packing pattern of the in situ rock mass has been destroyed. GSI is also not applicable to rock masses in which the individual rock particles or blocks are not in contact due to the presence of heavily sheared materials, weathered and altered materials and clays or other weak materials deposited into the rock matrix by whatever means. In such cases the rock blocks or particles can be considered to 'float' in a weak matrix, the shear strength of which should be determined by soil mechanics methodology."

Hence, the application of GSI and the Hoek-Brown criterion to the weak rocks discussed above must be treated with caution.

\subsection{Collapse processes in weak rocks}

The porosity of friable soft iron ores is divided into: (1) intergranular porosity, the traditional volume porosity defined as the volume of voids to the total volume, and (2) intragranular porosity, the porosity contained within the mineral grains. The intergranular porosity measured at three Vale mines in Brazil ranged from 12 to $23 \%$, with the total porosity ranging from 24 to $29 \%$ (Table 4). These porosities are similar to those associated with dense soils which range from $12 \%$ for well graded silty sand and gravel, to $29 \%$ for clean uniform sand (fine or medium). Porosity alone is not sufficient to characterise the engineering behaviour of a material. An additional parameter that can have a significant influence on material behaviour is the fabric. Inspection of Figure 18 illustrates that, even though the porosity of the material is the same, the fabric in Figure 18(a) is less susceptible to collapse behaviour than the fabric arrangement in Figure 18(b).

Table 4 Overall percentage by volume of intergranular and intragranular porosity, in three iron ore Vale mines in Brazil (from Costa, 2009)

\begin{tabular}{cccc}
\hline $\begin{array}{c}\text { Friable Soft Iron Ore } \\
\text { From }\end{array}$ & $\begin{array}{c}\text { Intergranular } \\
\text { Porosity (\%) }\end{array}$ & $\begin{array}{c}\text { Intragranular } \\
\text { Porosity (\%) }\end{array}$ & $\begin{array}{c}\text { Total } \\
\text { Porosity (\%) }\end{array}$ \\
\hline Tamanduá Mine & 23 & 4 & 27 \\
Capitão do Mato Mine & 12 & 12 & 24 \\
Mina das Águas Claras & 22 & 7 & 29 \\
Average & 19 & 8 & 25 \\
\hline
\end{tabular}



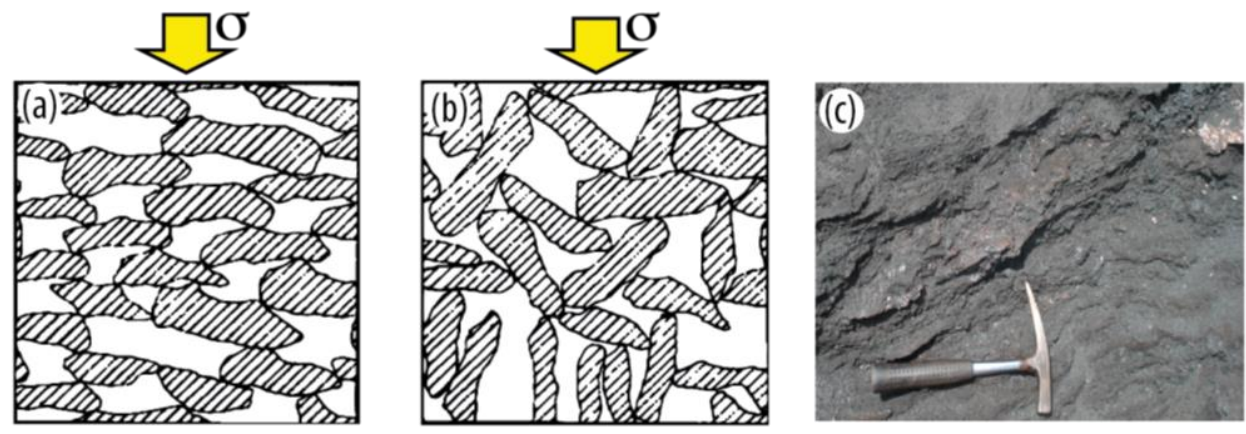

Figure 18 Role of loading direction and fabric of identical material (same porosity) on material behaviour; ( $a$ ) and (b); the packing arrangement in (b) is more susceptible to collapse compared to the packing arrangement in (a), modified from Holtz et al. (2011); (c) friable iron ore with high porosity (photo by T. Costa)

In addition to the potential for collapse, increasing porosity degrades the strength of a rock. Palchik (2011) compiled the laboratory uniaxial compressive strength for heterogeneous carbonate rocks. Those results are summarised in Figure 19 and clearly show a significant decrease in laboratory uniaxial compressive strength from 175 to $50 \mathrm{MPa}$, as porosity increases from 7 to $30 \%$. The sensitivity of the strength to porosity implies that site characterisation techniques must be adjusted so that the procedures do not destroy the very structure of the material that is being sampled.

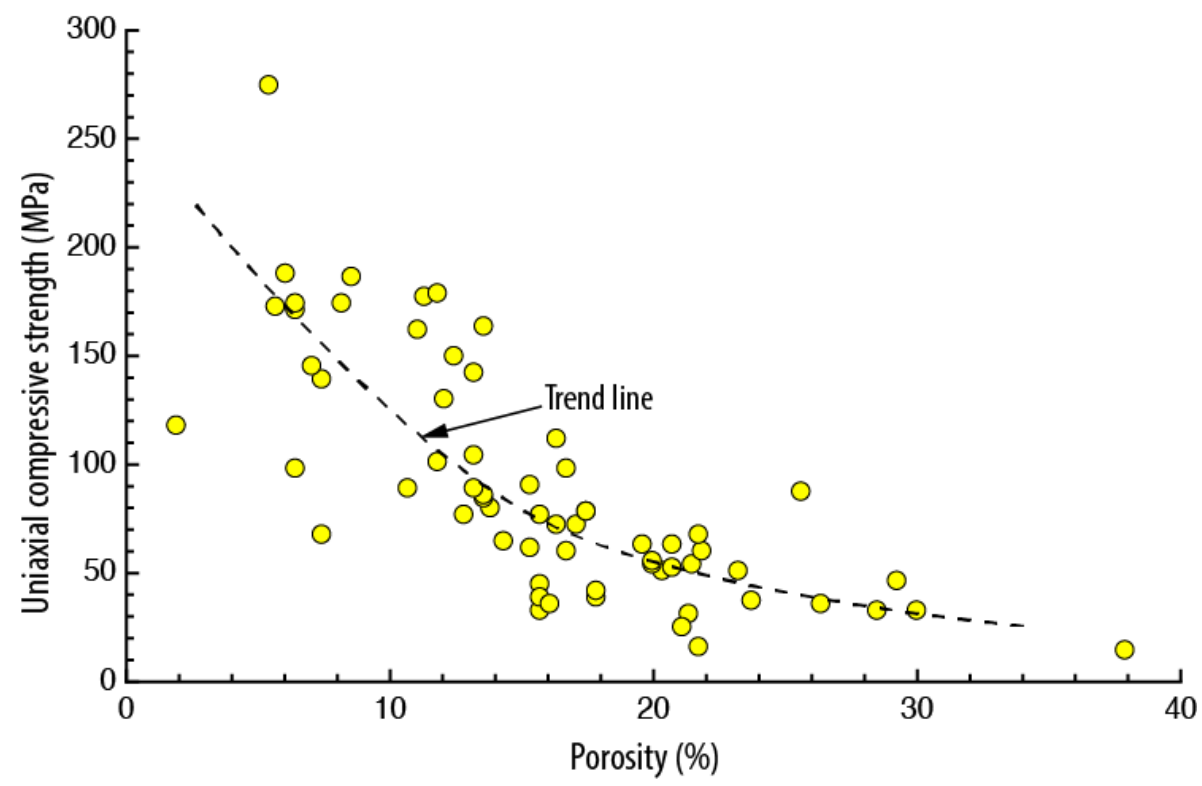

Figure 19 Relationship between porosity and the uniaxial compressive strength in carbonate rocks, data from Palchik (2011)

The behaviour and strength of the soft iron ores from Brazil were described by Costa (2009) and Sá (2010). Figure 20 shows the stress-strain response of the friable soft iron ores and the associated shear strength expressed using the traditional 'soil mechanics' mean effective principal stress and deviatoric stress. The testing by Costa (2009) was carried out at very low confining stresses (100 kPa) corresponding to approximately $5 \mathrm{~m}$ of overburden and these samples were tested perpendicular to the fabric. Even at this low confining stress, there was no evidence of a significant brittle response in the majority of the tests. It is clear from Figure 20 there is no evidence of the type of nonlinear failure envelope that is normally associated with Hoek-Brown behaviour.

Linear failure envelopes usually indicate that the failure process is dominated by a single mechanism, typically frictional sliding. Nonlinear envelopes indicate competing mechanisms, typically tensile fracturing at low confining stress and frictional sliding at high confining stress. Bishop (1966) compiled the strength of 
various soils under high confining stresses and these are summarised in Figure 21. Bishop showed that the friction angles ranged from 10 to $40^{\circ}$ as the material ranged from homogeneous clay through sand, to heterogeneous rockfill and silty sandy gravel. The increase in frictional strength is obtained by changing mineralogy, increasing grain size, packing and geometric dilation. The soft iron ore in Figure 20 has a friction angle of approximately $35^{\circ}$, which is equivalent to medium dense sand. This implies that the mineralogy is not playing a significant role in controlling the friction angle, but that it is controlled by the geometry of the granular material.

One of the features of high porosity weak rocks that display weak cohesive bonds in the undisturbed state is the potential for sudden collapse of the material. Steep slopes (Figure 22) that appear stable may suddenly collapse with little warning. Specialised testing by Sasitharan et al. (1993) showed how collapse surfaces in sand could be measured in the laboratory, and Dawson et al (1998) used their findings to illustrate how this collapse process occurred in mine waste dumps. A significant complexity in the laboratory testing of this collapse process is the presence of true cohesion, i.e., cementing agents.
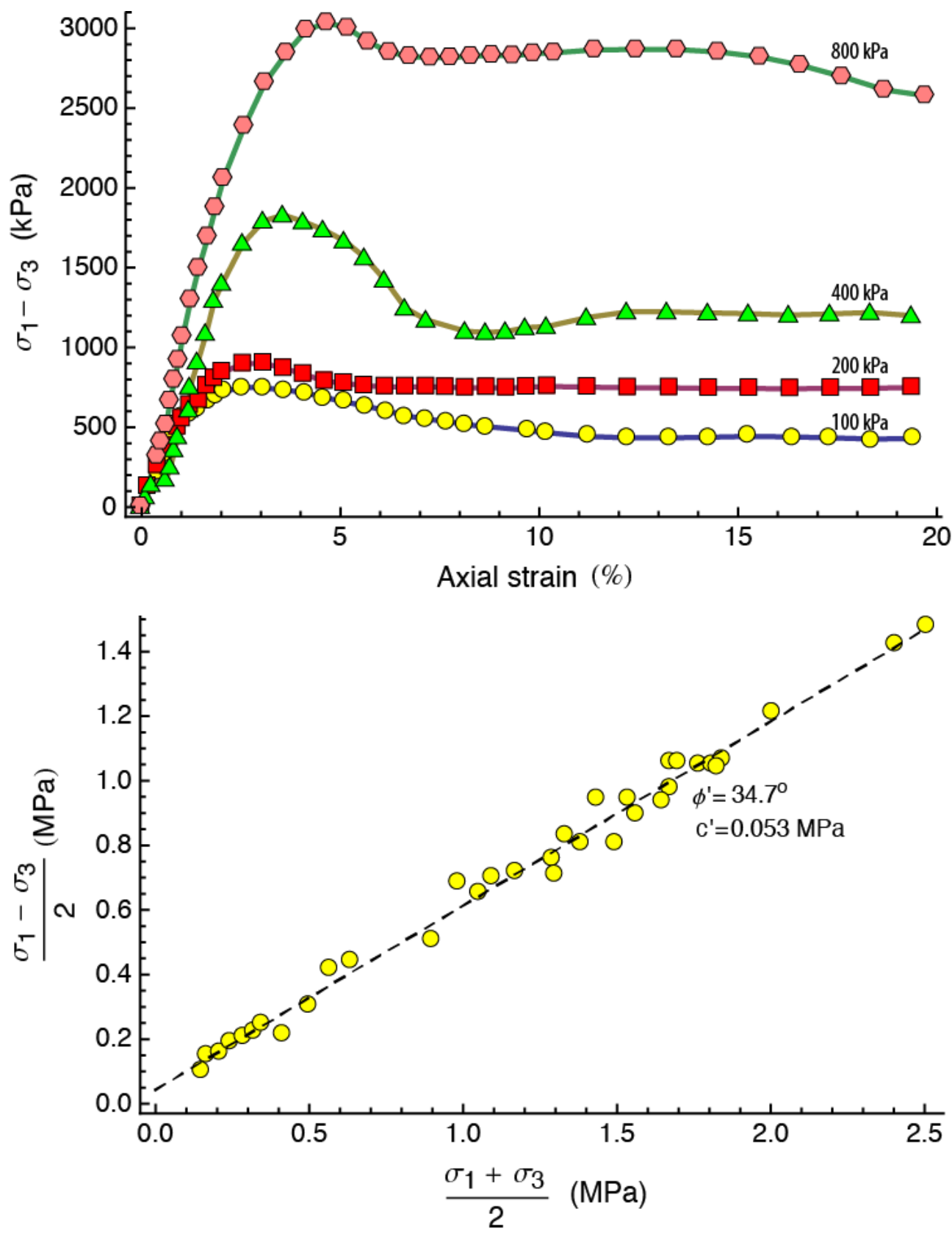

Figure 20 The stress-strain response for friable soft iron ores and the associated peak strength failure envelope, data (from Costa, 2009) 
Collapse processes in calcarenite and weakly cemented sandstones, where the cement is an iron oxide, have been reported by Carter et al. (1988), and Cuccovillo and Coop (1997). Their extensive testing showed that when initially compressed these materials are very stiff despite their high porosity. However, at relatively small deviatoric strains this stiffness shows a significant decrease as the sample is sheared (Figure 23(b)). In traditional triaxial testing, such as that shown in Figure 20, it is essentially impossible to determine when this change occurs. Airey (1993) showed the response for the calcarenite recorded with local strain measurements such as are typically used in hard rock testing. As shown in Figure 23(a), yielding is recorded by the lateral strain at point $A$ while yielding is not recorded by the axial strain until point $B$, and both points A and B occur well before peak strength is reached. Airey (1993) noted that this yielding recorded by the lateral strain at approximately $50 \%$ of the peak strength was observed in all the drained tests on the calcarenite.

The early yielding noted by Airey (1993) and the change in stiffness at small strains reported by Cuccovillo and Coop (1997), support the notion that the initial load is carried by the intergranular cohesive strength component. Because of the high porosity of these materials, once the cohesion is destroyed the loads are transferred to the granular material particle contacts mobilising the frictional strength. The challenge is to detect this subtle change using traditional testing techniques, as these changes occur at small strains. An additional complexity is the need to conduct effective stress testing with the practical issue of measuring local strains to help detect the pre-peak onset of yield. Despite the advances in laboratory testing this remains a challenge, except in research environments.

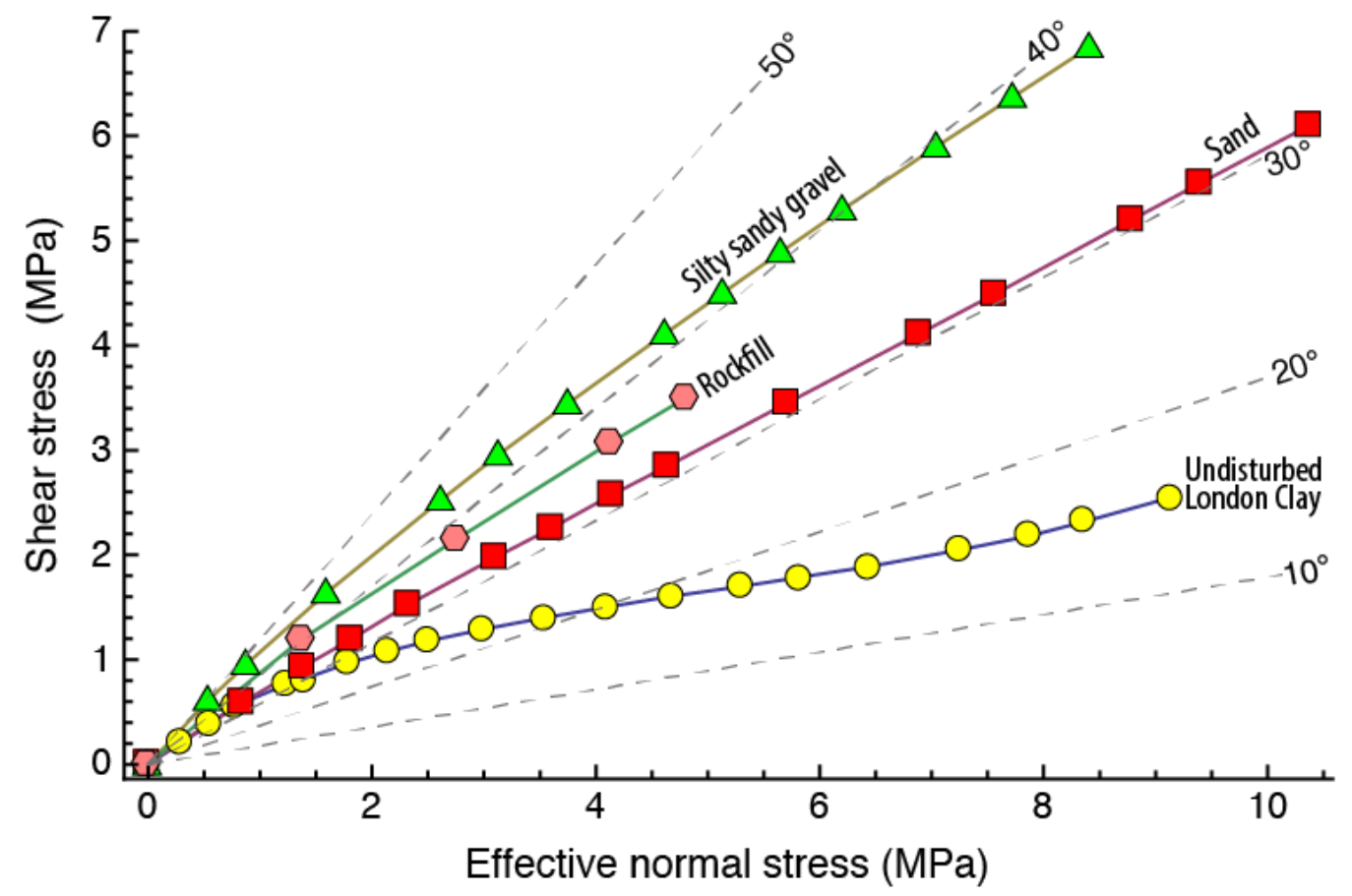

Figure 21 Mohr envelopes for soils under high confining stress (from Bishop, 1966) 


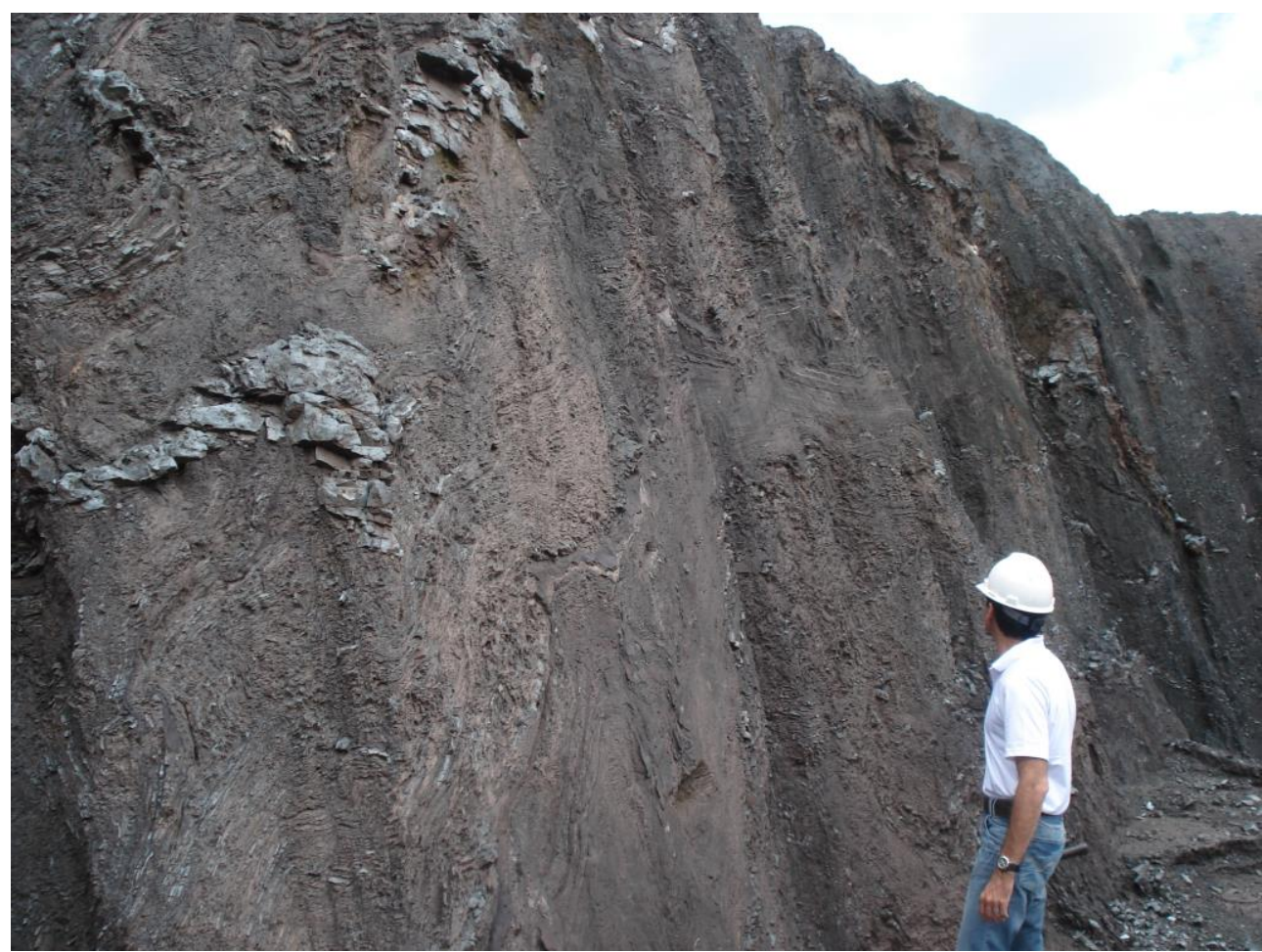

Figure 22 Example of steep slope in soft iron ores (photo by T. Costa)

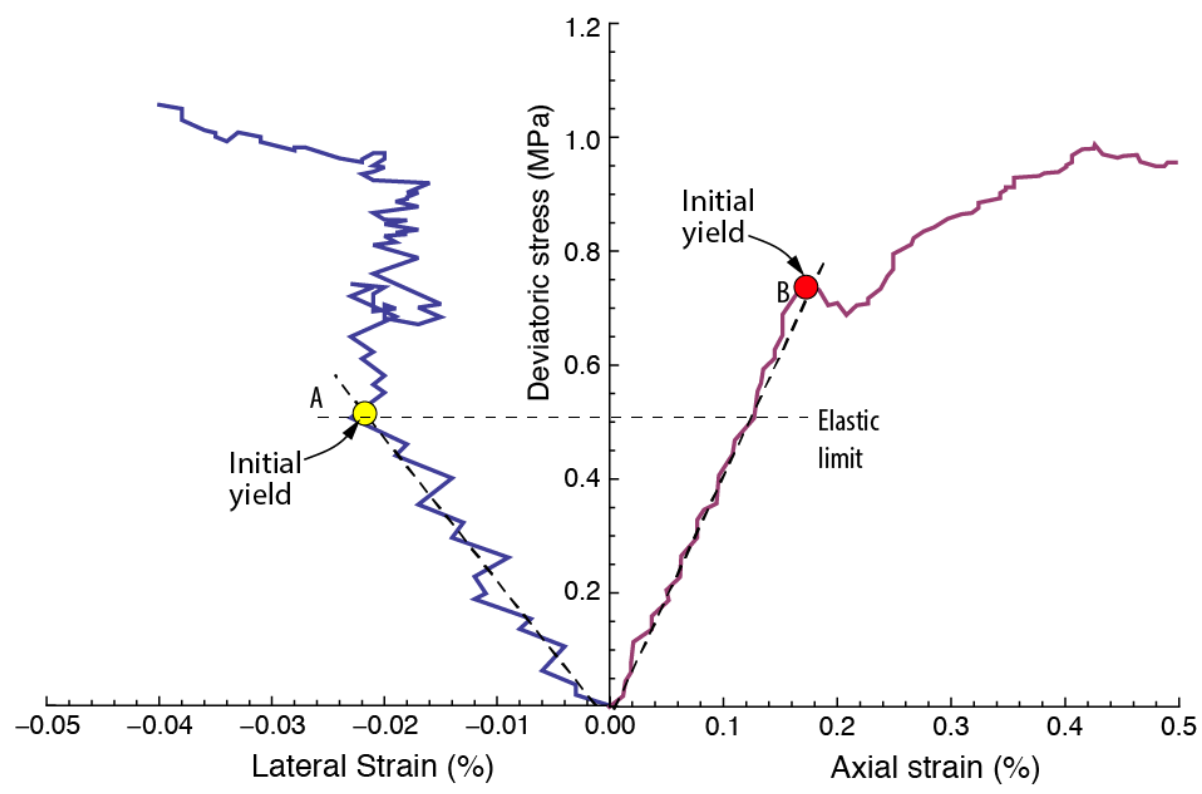

(a) 


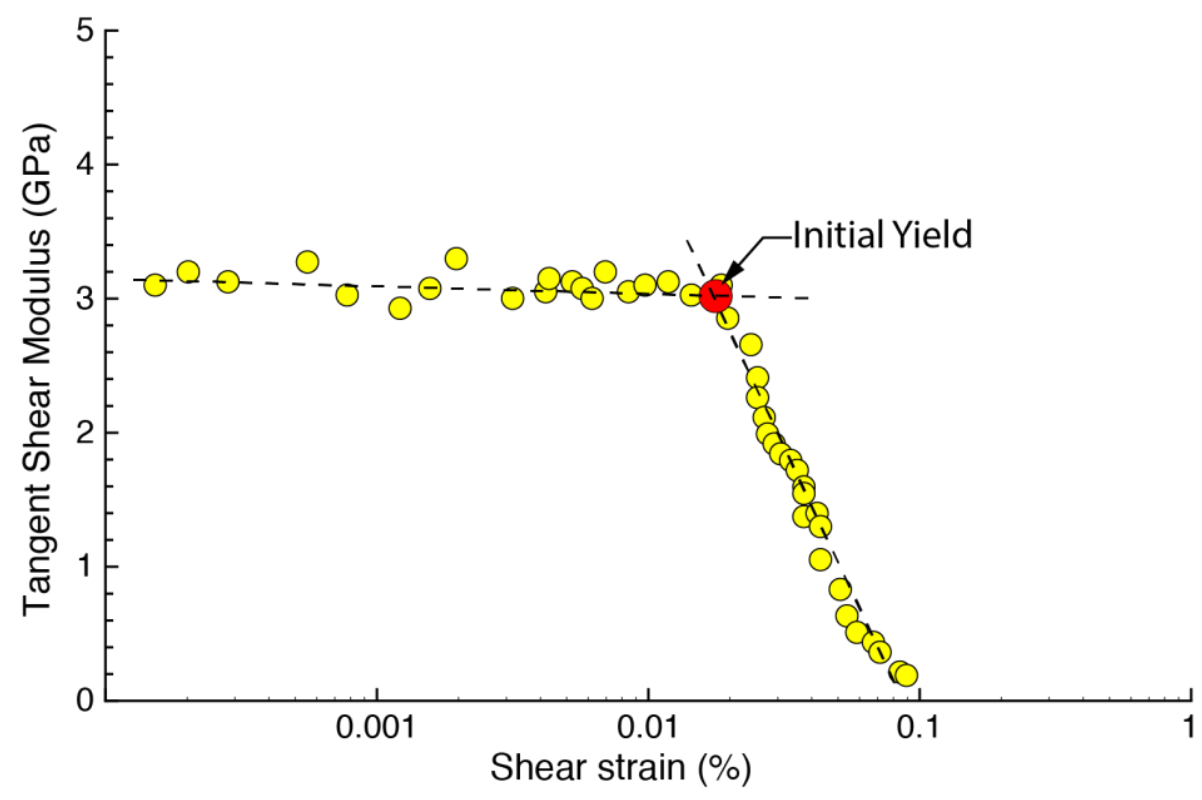

(b)

Figure 23 (a) Stress-strain response for calcarenite recorded by local strain measurement system showing the onset of yield before the peak strength is reached (modified from Airey 1993); (b) example of sudden change in shear stiffness in a cemented sandstone at small strains (modified from Cuccovillo and Coop, 1997)

One of the subtle issues highlighted by the data in Figure 23 is the importance of sampling and sample handling during site investigations. As previously discussed the porosity of some weak rocks, particularly weathered rocks, residual soils and these soft iron ores is very high and approaches that of soils. Hence, extracting high quality samples without disturbing the weak rock structure and in particular its cohesion of is extremely important. In such conditions special samplers, such as plastic inner tubes to core barrels and the Mazier corebarrel, should be used to minimise the effects of sample disturbance.

\subsection{Concept of cohesion loss in mudrocks}

In low permeability mudrocks, there are two prominent failure processes: (1) delayed failure and (2) progressive failure. Delayed failure was first described by Terzaghi (1936) who suggested that in 'stiff fissured clays' the lateral stress release that results from an excavation could cause opening of fissures and an increase of mass permeability. Softening of the intact material concentrated along the fissures reduces the average strength, which allows more deformations to occur. More fissures then open up and the process continues. This process, which became known as delayed failure and was used to explain slope failures that occurred years and decades after being constructed, leads to a failure envelope that represents cohesion-loss. As illustrated in Figure 24 there is only minor shear displacement associated with this change from peak to cohesion-loss. The behaviour of weak mudrocks is similar to the stiff fissured clays described by Terzaghi (1936) and Skempton (1964). The fundamental requirement is stress release and redistribution, caused by the pit excavation, and a material that softens/weakens in the presence of moisture. It is unlikely that this cohesion-loss process would be dominant in pit slopes that were only opened for a few years, but it is a factor that should be considered in pits with a long life. A pit slope in laterite material underlain by metasediments (greywacke and phyllite) recently experienced deep seated (35 m) slope instability after being inactive since 1999 (P. Carvill, pers. comm., 2013). While the slope failure may be classed as delayed failure, it is unclear at present if the rocks were moisture sensitive. 


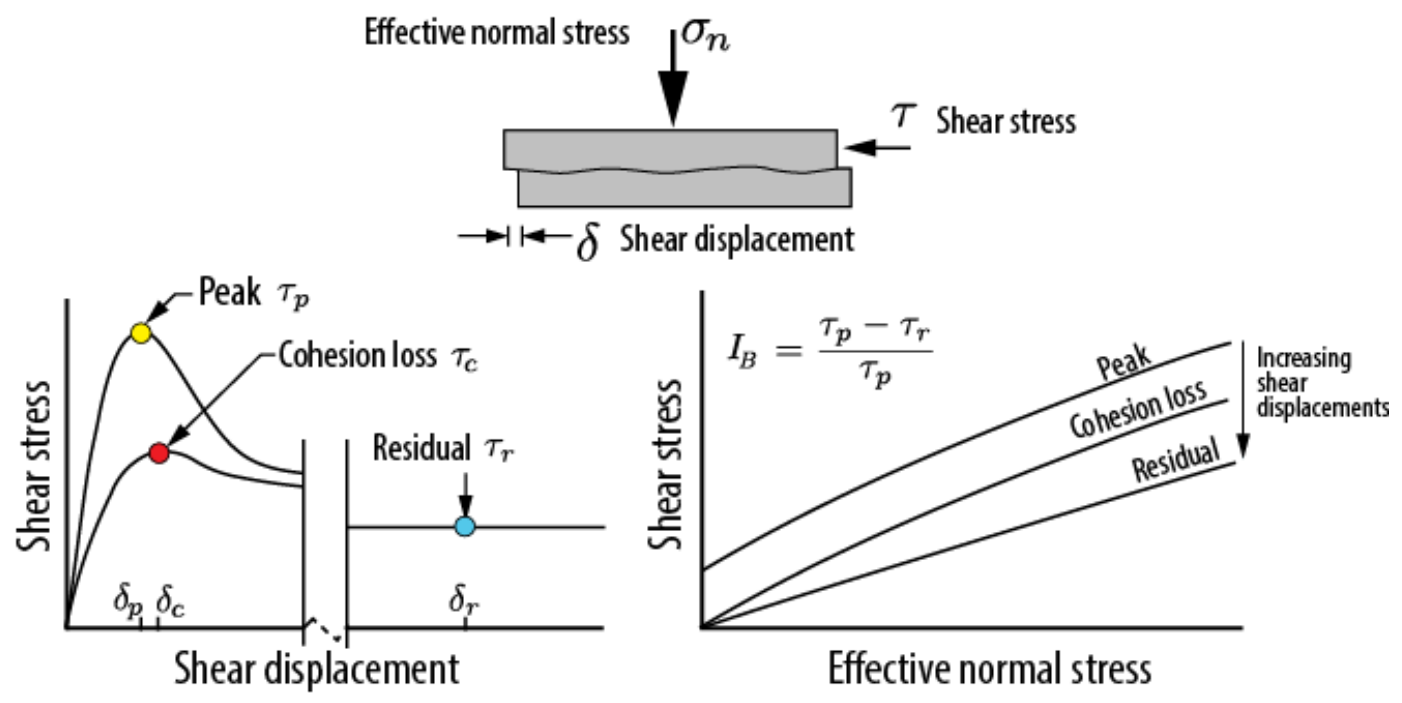

Figure 24 The failure envelope represented by cohesion loss

Progressive failure is also a well-known cohesion loss process that is often associated with slope failures in heavily overconsolidated weak mudrocks. The process requires:

1. Brittle material that has a residual strength less than the peak strength. Bishop defined this as the brittleness index $I_{B}$ (Figure 24).

2. Unloading stress release causing localised stress concentrations that result in large strains concentrated in thin layers (millimetres to centimetres thick).

Burland et al. (1977) documented failure in an open pit mined for brick clay. Using extensive instrumentation they demonstrated that the pit excavation resulted in strain localisation sufficient to develop a shear zone near the base of the excavation. The failure process, illustrated in Figure 25 concentrated along a thin weak layer, with the mass above this layer moving as a block. The process described by Burland et al. (1977) is generally referred to as progressive failure. While Cooper et al. (2011) do not suggest progressive failure processes as the mechanism leading to the formation of the bedding plane shears in the Cobre Las Cruces open pit, their careful documentation supports the progressive failure processes illustrated in Figure 25.

The description of the failure process observed in the Cobre Las Cruces open pit highlights another process that is synonymous with progressive failure namely, loosening. Stress release associated with the pit excavation allows the jointing within the mass to open, providing an overall loosened state. This loosening process was also reported by Small and Morgenstern (1992) when examining the performance of a highwall in soft mudrocks at the Highvale coal mine, Alberta. Overall loosening of the pit walls also results in a loss of cohesion. While jointed mudstones will lose strength as the lateral strains increase, a more serious consequence of this loosening is the enhanced pathways for water infiltration. The typical failure mode is for the mudrocks to move as a series of blocks to which water pressure, particularly from heavy rains, can serve as an additional driving force that can accelerate the movement and lead to sudden failure. Esu et al. (1984) described the failure of a $150 \mathrm{~m}$ deep open pit in mudrocks and sandstones used to extract a coal seam. Gradual horizontal movements and associated surface settlement were recorded and after 41 months there were obvious signs of opening of the joints near the toe of the slope. A few days after two closely spaced rainstorm events the movements rapidly accelerated and resulted in failure of the pit wall. The angle of the pit wall at the time of failure was only $17.4^{\circ}$. 


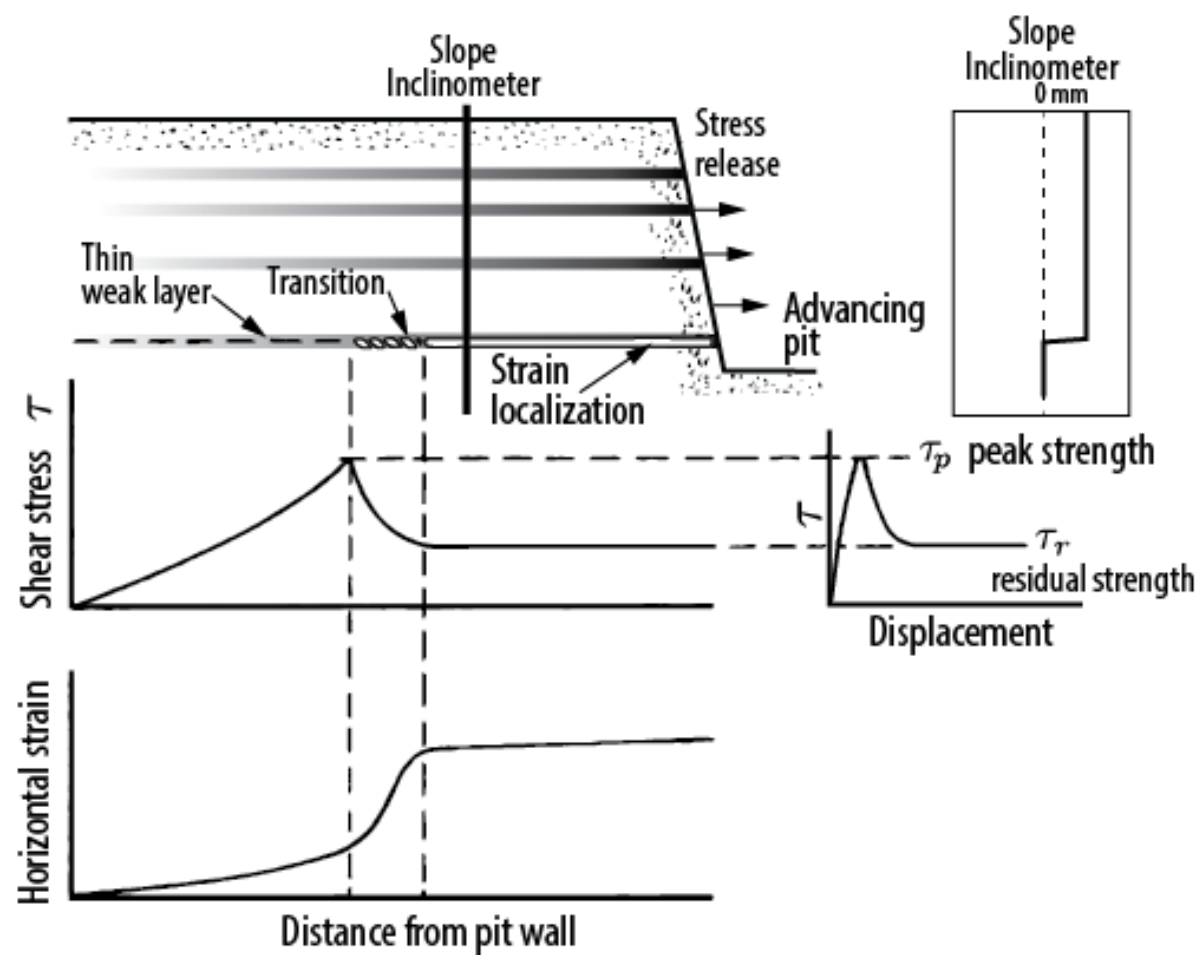

Figure 25 Illustration of progressive failure on a localised shear band in an open pit, modified from Burland et al. (1977)

Time-dependent processes such as delayed failure, and progressive failure are often competing cohesion loss processes. As it takes years for a pit to be developed, it is often difficult, if not impossible, to separate these processes, which more often than not, act together in reducing the available cohesion of the rock mass. Regardless of the cause, case histories show that the operational strength of slopes constructed in this category of weak rocks is less than that measured in the laboratory. For mudrocks the operational strength is often $50 \%$ or less of the laboratory strength.

\subsection{Discussion}

The discussions above demonstrate that establishing design strengths for pit slopes in weak rocks is challenging and that failure criteria are process driven. A fundamental assumption with the traditional Mohr-Coulomb failure envelope is that the two strength components cohesion and friction are mobilised instantly and simultaneously. The wisdom in that assumption was first questioned by Schmertmann and Osterberg (1960) who demonstrated using laboratory tests that the cohesive and frictional strength components were mobilised as a function of plastic strain. Hence there is no unique failure envelope; it simply depends on the plastic strain and the associated cohesion and friction developed in the material. The concept introduced by Schmertmann and Osterberg (1960) is illustrated in Figure 26.

An alternative interpretation to the linear failure envelopes as a function of plastic strain is that the failure envelope can be represented by a nonlinear function with zero cohesion, implying that the shear strength is only a function of friction and geometric interlocking (Figure 26). In frictional material that has no interlocking, a limiting failure envelope can also be specified by the critical state line (CSL). The nonlinear and the CSL frictional failure envelopes may be appropriate for many civil earth structures, particularly when projects must be designed for 50+ years. Open pit operators however seldom deal with such materials and need to balance conservatism against economical pit slope designs. To find this balance requires better approaches for defining strength parameters and failure criteria for weak rocks. 

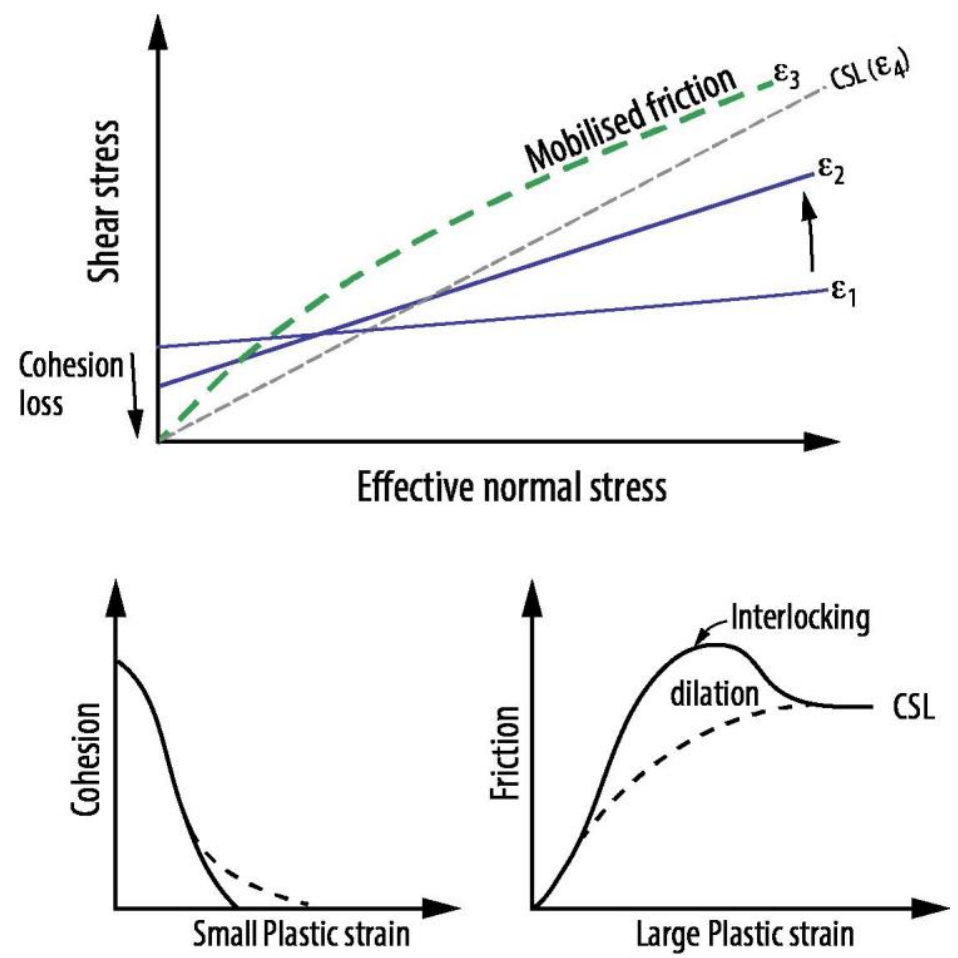

Figure 26 Illustration of the failure envelopes as a function of plastic strain, involving friction mobilisation and cohesion loss

Today, monitoring of the pit wall deformations indirectly provides one approach. Zavodni (2000) reviewed time-dependent deformations observed in open pit mines and proposed various responses related to amount and rates of deformation. Brox et al. (2003) and Newcomen et al. (2003) consider strain as a potential indicator for managing displacements at Highland Valley Copper pit walls. More recently Simmons (2011) considered extensional strain as a pre-failure indicator in bedded deposits. While design is often carried out using a Factor of Safety based on limit equilibrium there is no theoretical linkage of measured pit wall displacements to the design Factor of Safety. Hence, if displacement monitoring is to be linked to design and forecasting ground behaviour, a reliable relationship is needed between displacements and rock mass strength. Figure 26 suggests one approach that can be used in numerical simulations, i.e. cohesion and friction as a function of plastic strain. However, regardless of the methodology, in order to advance our predictive capabilities for rock mass strength, the process for how that strength is mobilised must be considered.

\section{$4 \quad$ Summary}

The Large Open Pit project sponsors recognised that the current LOP open pit slope design guidelines do not address design issues for pit slopes in materials generally classed as 'weak rocks'. Canvassing of the LOP sponsors and their affiliates resulted in identifying pit slope issues in the following general weak rock categories: (1) cemented transported sediments, (2) saprolites (residual soils and weathered rocks); (3) leached rocks/soft iron ores; (4) mudrocks, and (5) hydrothermally altered rocks. Case histories compiled demonstrate the instability processes that should be considered in the designing the pit slopes in these weak rocks. While the strength of hard rocks is traditionally established using rock mass classifications and the Hoek-Brown failure criterion, there is ample evidence that these approaches are not capturing the failure processes evident in weak rocks.

The two prominent failure processes in weak rocks identified in this paper are: (1) cohesion loss processes and (2) collapse processes. While the cohesion loss processes, such as delayed failure, progressive failure and loosening have been examined in other material such as stiff clays, the collapse processes in leached rocks and saprolites, including soft iron ores, appear to be more complex. The traditional testing and 
characterisation techniques used in soil mechanics and hard rocks may not be adequate for the latter instability mechanism. The soft iron ores, while friable and easily eroded by surface water flow, can stand steeply over bench-scale heights and relatively steeply over multiple bench heights, but experience has shown that when these materials are put under stress, slope failures can be very rapid, with long runouts. This failure process appears to involve 'collapse' of the cemented grain structure, with the materials essentially degrading to the individual grains that then 'flow', as though liquefied. Quantifying the stresses, i.e. pit geometry that will lead to a sudden collapse in weak rocks and particularly the soft iron ores, remains a challenge.

\section{Acknowledgement}

The authors thank: (1) the Large Open Pit sponsors for their support and acknowledge the contributions of the LOP Weak Rock Committee (Stuart Anderson, Teck Resources; Téo Costa, Vale; Martyn Robotham, Rio Tinto; Bob Sharon, Newmont; and Eric Schwarz, Barrick); (2) John Read and Renato Macciotta for their review comments, (3) Peter Knight of Newcrest Mining Ltd and, Mark Fowler of Pells Sullivan Meynink Engineering Consultants for supplying the Lihir case history.

\section{References}

Airey, D.W. (1993) Triaxial Testing of Naturally Cemented Carbonate Soil, Journal of Geotechnical Engineering, American Society of Civil Engineers, Vol. 119, No. 9, pp. 1379-1398.

Beale, G. and Read, J. (2013) Guidelines for Evaluating Water in Pit Slope Stability, CSIRO Publishing, Melbourne, Australia.

Bishop, A.W. (1966) The Strength of Soils as Engineering Materials, Géotechnique, Institution of Civil Engineers, Vol. 16, No. 2, pp. 91-130.

Brown, E.T. (1981) Rock Characterization, Testing and Monitoring, ISRM Suggested Methods, Pergamon Press, Oxford.

Brox, D.R. and Newcomen, H.W. (2003) Utilizing strain criteria to predict highwall stability performance, in Proceedings 10th ISRM Congress, 8-12 September 2003, Sandton, South Africa, International Society for Rock Mechanics, Lisboa, pp. 1-7.

Burland, J.B., Longwoth, T.I. and Moore, J.F.A. (1977) A study of ground movement and progressive failure caused by a deep excavation in Oxford Clay, Géotechnique, Institution of Civil Engineers, Vol. 27, No. 4, pp. 557-591.

Carter, J.P., Kaggwa, W.S., Johnston, I.W., Novello, E.A., Fahey, M. and Chapman, G.A. (1988) Triaxial testing of North Rankin calcarenite, in Proceedings International Conference on Calcareous Sediments, R.J. Jewell and M.S. Khorshid (eds), 15-18 March 1988, Perth, Australia, Balkema, Rotterdam, Vol. 2, pp. 515-530.

Cooper, S., Perez, C., Vega, L., Galera, J.M. and Pozo, V. (2011) The Role of Bedding Planes in Guadalquivir Blue Marls on the Slope Stability in Cobre Las Cruces Open Pit, in Proceedings International Symposium on Rock Slope Stability in Open Pit Mining and Civil Engineering (Slope Stability 2011), 18-21 September 2011, Vancouver, Canada, Canadian Rock Mechanics Association, Canada, CD-rom only.

Costa, T. (2009) Caracterização Geológico-Geotécnica e Modos de Ruptura do Minério Hematítico Friável nas Minas da Vale, Borda Oeste do Quadrilátero Ferrífero, MG. Universidade Federal de Ouro Preto Nugeo Núcleo de Geotecnia da Escola de Minas Mestrado Profissional em Engenharia Geotécnica.

Cuccovillo, T. and Coop, M.R. (1997) Yielding and pre-failure deformation of structured sands, Géotechnique, Institution of Civil Engineers, Vol. 47, No. 3, pp. 491-508.

da Franca, P.R.B. (1997) Analysis of Slope Stability using Limit Equilibrium and Numerical Methods with Case Examples from the Águas Claras Mine, Brazil, MSc Thesis, Department of Mining Engineering, Queen's University, Kingston, Canada.

Dawson, R.F., Morgenstern, N.R. and Stokes, A.W. (1998) Liquefaction flowslides in Rocky Mountain coal mine waste dumps, Canadian Geotechnical Journal, NRC Research Press, Vol. 35(2), pp. 328-343.

Deere, D. and Patton, F. (1971) Slope stability in residual soils, in Proceedings 4th Panamerican Conference on Soil Mechanics and Engineering Foundation, June 1971, San Juan, Puerto Rico, America Society of Civil Engineers, New York, No. 1, pp. 87-170.

Esu, F., Distefano, D., Grisolia, M. and Tancredi, G. (1984) Stability of a High Cut in Overconsolidated Lacustrine Deposits, in Proceedings IV International Symposium on Landslides, 16-21 September 1984, Toronto, Canada, Canadian Geotechnical Society, Richmond, Vol. 2, pp. 63-68.

Fookes, P.G. (1990) Tropical Residual Soils Geological Society Engineering Group Working Party Report, Quarterly Journal of Engineering Geology and Hydrogeology, Geological Society of London, Vol. 23, No. 1, pp. 4-101.

Grainger, P. (1984) The classification of mudrocks for engineering purpose, Quarterly Journal of Engineering Geology and Hydrogeology, Geological Society of London, Vol. 17, No. 4, pp. 381-387.

Hencher, S.R. and Lee, S.G. (2010) Landslide mechanisms in Hong Kong, Engineering Geology Special Publications, Geological Society of London, Vol. 23, pp. 77-103.

Hoek, E., Carranza-Torres, C. and Corkum, B. (2002) Hoek-Brown failure criterion - 2002 edition, in Proceedings 5th North American Rock Mechanics Symposium and 17th Tunnelling Association of Canada Conference: NARMS- TAC, R. Hammah, W. Bawden, J. Curran and M. Telesnicki (eds), 7-10 July 2002, Toronto, Canada, University of Toronto Press, Toronto, Vol. 1, pp. 267-273. 
Holtz, R.D., Kovacs, W.D. and Sheahan, T.C. (2011) An introduction to geotechnical engineering, 2nd edition, Prentice Hall.

Lumb, P. (1975) Slope failures in Hong Kong, Quarterly Journal of Engineering Geology and Hydrogeology, Geological Society of London, Vol. 8, No. 1, pp. 31-65.

Marinos, P. and Hoek, E. (2000) GSI: A geological friendly tool for rock mass strength estimation, in Proceedings GeoEng2000, An International Conference on Geotechnical \& Geological Engineering, 19-24 November 2000, Melbourne, Australia, Technomic Publishing Co. Inc., Lancaster, Vol. 1, pp. 1422-1440.

Newcomen, H.W., Maggs, C. and Shwydiuk, L. (2003) Managing Pit Slope Displacements: Highland Valley Copper's Lornex Pit Southwest Wall, Canadian Institute of Mining and Metallurgy Bulletin, Canadian Institute of Mining and Metallurgy, Vol. 96, No. 1071, May 2003.

Norbury, D., Hencher, S., Cripps, J. and Lumsden, A. (1995) The Description and Classification of Weathered Rocks for Engineering Purposes - Geological Society Engineering Group Working Party Report, Quarterly Journal of Engineering Geology, Geological Society of London, Vol. 28, pp. 207-242.

Palchik, V. (2011) On the Ratios between Elastic Modulus and Uniaxial Compressive Strength of Heterogeneous Carbonate Rocks, Rock Mechanics and Rock Engineering, Springer, Vol. 44, No. 1, pp. 121-128.

Potter, P.E., Maynard, J.B. and Depetris, P.J. (2005) Mud and Mudstones, Springer, DOI: 10.1007/b138571, ISBN: 978-3-540-221579, $297 \mathrm{p}$.

Read, J. and Stacey, P., (2009) Guidelines for Open Pit Slope Design, CRC Press/Balkema.

Rolland, C. (1998) A Comprehensive View of Process Engineering, in Proceedings 10th International Conference CAiSE' 98 , Lecture Notes in Computer Science 1413, B. Pernici and C. Thanos (eds), 8-12 June 1998, Pisa, Italy, Springer-Verlag, Berlin.

Sá, G. (2010) Caracterização litoestrutural e parametrização geomecânica das superfícies de ruptura em taludes da mina de N4E Carajás, Para, Brazil, Mestrado Profissional em Engenharia Geo, Universidade Federal de Ouro Preto Escola de Minas, NUGEO.

Santi, P. (2006) Field methods for characterizing weak rock for engineering, Environmental and Engineering Geoscience, The Geological Society of America, Vol. 12, No. 1, p. 1.

Sasitharan, S., Robertson, P.K., Sego, D.C. and Morgenstern, N.R. (1993) Collapse behavior of sand, Canadian Geotechnical Journal, NRC Research Press, Vol. 30, pp. 569-577.

Schmertmann, J.H. and Osterberg, J.O. (1960) An experimental study of the development of cohesion and friction with axial strain in saturated cohesive soils, in Proceedings Research Conference on Shear Strength of Cohesive Soils, June 1960, Boulder, USA, American Society of Civil Engineers, Reston, pp. 643-694.

Simmons, J.V. (2011) Extensional deformation triggers for potential composite failure of bedded rock slopes, in Proceedings International Symposium on Rock Slope Stability in Open Pit Mining and Civil Engineering (Slope Stability 2011), E. Eberhardt and D. Stead (eds), 18-21 September 2011, Vancouver, Canada, Canadian Rock Mechanics Association, Canada, CD-rom only.

Skempton, A. (1964) Long-term stability of clay slopes, Géotechnique, Institution of Civil Engineers, Vol. 14, No. 2, pp. 81-107.

Small, C.A. and Morgenstern, N.R. (1992) Performance of a highwall in soft rock, Highvale mine, Alberta, Canadian Geotechnical Journal, NRC Research Press, Vol. 29, No. 3, pp. 353-363.

Sullivan, T.D. (2007) Hydromechanical coupling and pit slope movements, in Proceedings International Symposium on Rock Slope Stability in Open Pit Mining and Civil Engineering (Slope07), Y. Potvin (ed), 12-14 September 2007, Perth, Australia, Australian Centre for Geomechanics, Perth, pp. 3-43.

Terzaghi, K. (1936) Stability of slopes of natural clay, First International Conference on Soil Mechanics and Foundation Engineering, 22-26 June 1936, Cambridge, USA, Harvard University, Cambridge, pp. 149-153.

Watters, R. and Delahaut, W. (1995) Effect of argillic alteration on rock mass stability, Clay and Shale Slope Instability, W.C. Haneberg and S.A. Anderson (eds), Geological Society of America Reviews in Engineering Geology, Geological Society of America, Vol. 10, pp. 139-150.

Wesley, L. D. (2010) Geotechnical Engineering in residual soils, John Wiley \& Sons.

Zavodni, Z.M. (2000) Time-dependent movements of open-pit slopes, in Slope Stability in Surface Mining, W.A. Hustrulid, M.K. McCarter and D.J.A. Van Zyl (eds), Society of Mining, Metallurgy and Exploration Inc., Littleton, USA, pp. 81-87. 